(2) norden 



\section{Elektroniske resepter over landegrenser i norden}

Nordisk eHelseforum

TemaNord 2009:566 
Elektroniske resepter over landegrenser i norden

Nordisk eHelseforum

TemaNord 2009:566

(c) Nordisk Ministerråd, København 2009

ISBN 978-92-893-1924-9

Trykk: Kailow Express ApS

Opplag: 80

Trykt på miljøvennlig papir som oppfyller kravene i den nordiske miljøsvanemerkeordning. Publikasjonen kan bestilles på www.norden.org/order. Flere publikasjoner på www.norden.org/publikationer

Printed in Denmark

Nordisk Ministerråd

Store Strandstræde 18

1255 Copenhagen $\mathrm{K}$

Telefon (+45) 33960200

Fax (+45) 33960202

\section{Nordisk Råd}

Store Strandstræde 18

1255 Copenhagen $\mathrm{K}$

Telefon (+45) 33960400

Fax (+45) 33111870

www.norden.org

\section{Det nordiske samarbeidet}

Det nordiske samarbeid er en av verdens mest omfattende regionale samarbeidsformer. Samarbeidet omfatter Danmark, Finland, Island, Norge og Sverige, samt de selvstyrende områdene Færøyene, Grønland og Åland.

Det nordiske samarbeid er både politisk, økonomisk og kulturelt forankret, og er en viktig medspiller i det europeiske og internasjonale samarbeid. Det nordiske fellesskap arbeider for et sterkt Norden i et sterkt Europa.

Det nordiske samarbeid ønsker å styrke nordiske og regionale interesser og verdier i en global omverden. Felles verdier landene imellom er med til å styrke Nordens posisjon som en av verdens mest innovative og konkurransekraftige regioner. 


\section{Innhold}

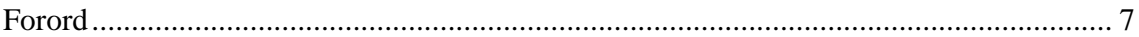

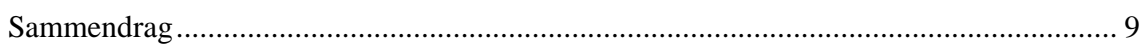

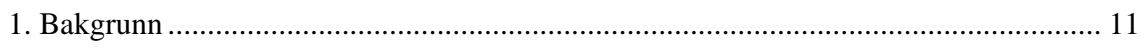

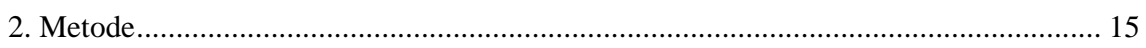

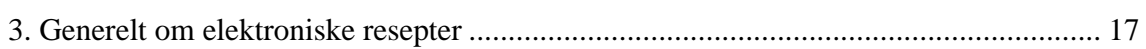

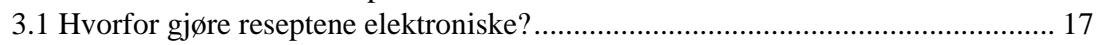

3.2 Hva er en elektronisk resept? ............................................................................ 19

3.3 Ulike løsninger for elektronisk resept................................................................... 19

4. Elektroniske resepter over landegrensene i Norden - hvorfor? ................................... 21

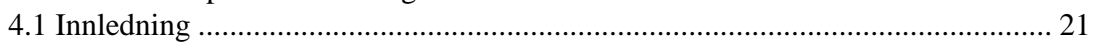

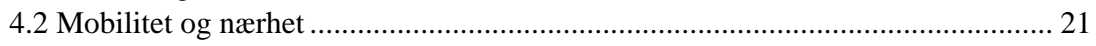

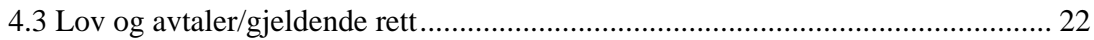

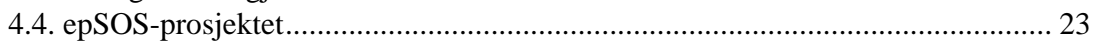

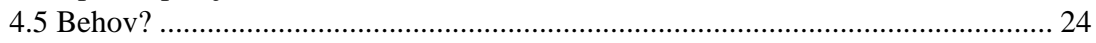

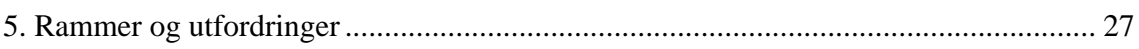

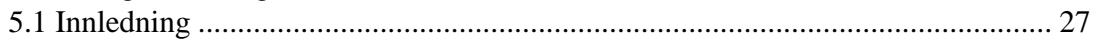

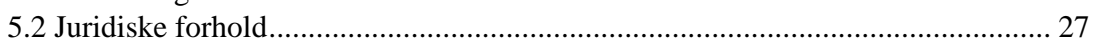

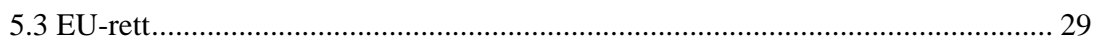

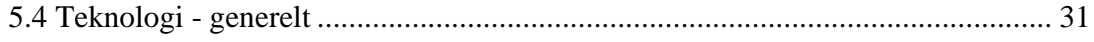

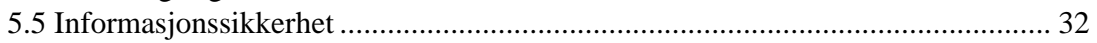

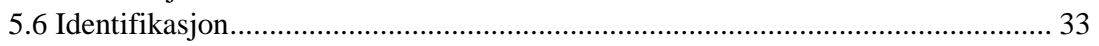

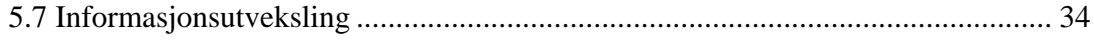

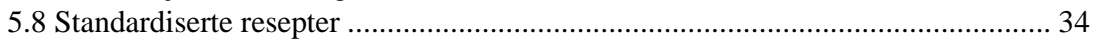

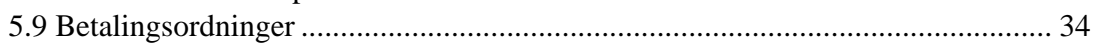

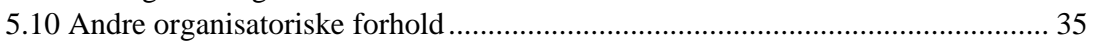

6. Elektronisk resept i de nordiske land - kartlegging .................................................... 37

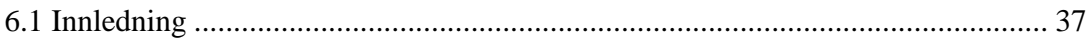

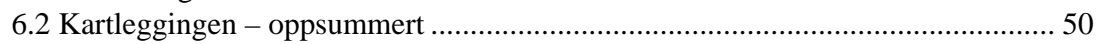

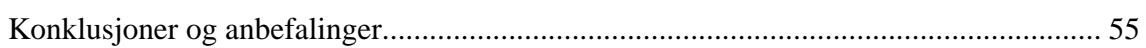

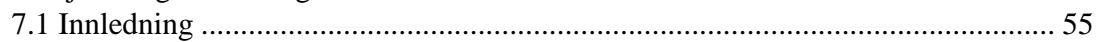

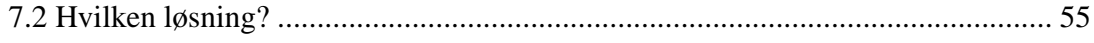

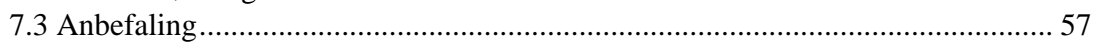

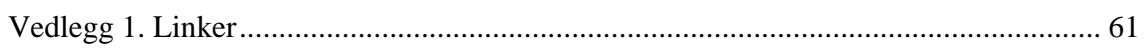

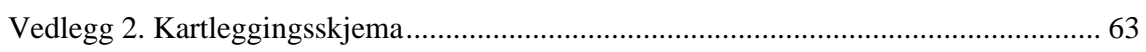





\section{Forord}

Denne rapporten er utarbeidet av Leif Erik Nohr ved Nasjonalt senter for samhandling og telemedisin, Tromsø, Norge, på vegne av Nordisk eHelseforum. Medlemmene av forumet og medlemmene av Nordisk juristnettverk for eHelse har gitt viktige bidrag både i prosessen frem til ferdigstillelse av rapporten og ikke minst i forbindelse med gjennomføring av kartleggingen av elektroniske resepter i de nordiske landene.

2. juni 2009 



\section{Sammendrag}

Det er en rekke utfordringer som må identifiseres, analyseres og løses før man kan få til et system der elektroniske resepter fra ett nordisk land kan behandles ved et hvilket som helst apotek i et annet.

I rapporten vil vi si noe om hva elektroniske resepter er og hvorfor dette har vært - og er - en så vidt viktig satsing i alle de nordiske landene. Vi ser også på argumenter for og mot det å utvide de nasjonale løsningene til et felles nordisk system.

Sentralt i vår analyse står en kartlegging vi har gjennomført i de nordiske landene og som har gitt oss et bedre bilde av status for bruk og innføring av e-resept, de juridiske rammeverket, organiseringen av e-reseptordningene samt de teknologiske løsningene og rammene. På bakgrunn av kartleggingen har vi gjort en foreløpig analyse av noen av de viktigste utfordringene for etablering av et nordisk system.

I løpet av noen år vil alle de nordiske landene ha på plass elektronisk resepthåndtering og etter hvert vil elektroniske resepter helt overta for papirresepten. Dersom det nordiske samarbeidet på området og den nordiske overenskomsten om gjensidig godkjennelse av resepter skal ha mening og innhold i fremtiden er det helt nødvendig at resepter kan behandles elektronisk også over landegrensene.

Rapporten anbefaler fortsatt fokus på arbeidet med å finne en felles nordisk e-reseptløsning. Funnene i rapporten viser imidlertid at de nordiske land er på til dels svært ulike stadier i innføringen av e-resepter og at det derfor enda vil ta noen år før det nødvendig og mulig å innføre et regionalt system. Rapporten anbefaler å følge og samarbeide med relevante prosjekter og initiativer på nordisk og europeisk nivå. 



\section{Bakgrunn}

Nordisk eHelseforum (NeHF) har i perioden 2008-2009 hatt særlig fokus på hvilke muligheter som foreligger for å få til løsninger der elektroniske resepter kan utveksles på tvers av landegrensene i Norden.

Utgangspunktet for dette arbeidet er for det første at alle de nordiske landene enten har tatt i bruk elektroniske resepter eller har konkrete planer og prosjekter i gang for å ta disse i bruk. Videre foreligger det allerede et langt og godt samarbeid mellom landene i Norden når det gjelder tradisjonelle resepter og i flere tiår har landenes lovgivning vært harmonisert slik at de nordiske land anerkjenner hverandres resepter. En tredje grunn til at dette utredningsarbeidet har kommet i gang ligger i selve grunnlaget for NeHF og forløperen Nordisk forum for telemedisin: I alle de nordiske landene tas moderne informasjons- og kommunikasjonsteknologi i bruk i stadig større grad innenfor helsesektoren og alle landene har ambisiøse planer for utvikling av telemedisinske og eHelsetjenester. Endelig er det jo også slik at det er en forholdsvis stor mobilitet av borgere mellom de nordiske landene. Dette er både mobilitet knyttet til ferie og turisme og mobilitet knyttet til arbeid og utdanning.

Denne rapporten oppsummerer forumets vurderinger. Vi har sett på status for implementering og bruk av elektroniske resepter i de nordiske landene, vi har forsøkt å analysere behovet for å utvide de nasjonale løsningene til en regional - nordisk - løsning og vi kommer her med noen anbefalinger både med hensyn til mulige løsningsmodeller og videre arbeid.

Rapporten er utarbeidet av Leif Erik Nohr, Nasjonalt senter for samhandling og telemedisin, Tromsø, med bidrag fra medlemmene i Nordisk eHelseforum og forumets sekretariat samt Nordisk Juristnettverk for eHelse. 
Medlemmer av Nordisk eHelseforum:

Danmark Elisabeth Hersby, Sundhedsstyrelsen Lars Hulbcek, MedCom

Finland Päivi Hämäläinen, Terveyden ja Hyvinvoinnin Laitos, Institutet för Hälsa och välfärd

Færøyene $\quad$ Tummas i Garði, Landssygehuset, Torshavn

Island Ingimar Einarsson, Heilbrigðisráðuneytið Gunnar Alexander Ólafsson, Heilbrigðisráðuneytið

Norge Kristian Skauli, Helsedirektoratet

Sverige Daniel Forslund, Socialdepartementet

Grønland Lars Ragus, Familie- og sundhedsdepartementet

Nordic Tele- $\quad$ Jarmo Reponen, Raahe Hospital medicine

Association

Medlemmer i Nordisk juristnettverk for eHelse:

Maria Jacobsson $\quad$ Socialstyrelsen, Sverige

Elisabeth Hersby Sundhedsstyrelsen, Danmark

Päivi Salo Social- och Helsovårdsministeriet, Finland

Áslaug Einarsdóttir Heilbrigðisráðuneytið, Island

Siri Pernille Utkilen Helsedirektoratet, Norge

Ellen Kari Christiansen Nasjonalt senter for samhandling og telemedisin, Norge

Leif Erik Nohr Nasjonalt senter for samhandling og telemedisin, Norge 
Sekretariatet for Nordisk eHelseforum:

Elin Anne Breivik Nasjonalt senter for samhandling og telemedisin, Norge

elin.anne.breivik@telemed.no

Leif Erik Nohr

Nasjonalt senter for samhandling og telemedisin, Norge

leif.erik.nohr@telemed.no

Ellen Kari Christiansen Nasjonalt senter for samhandling og telemedisin, Norge

ellen.christiansen@telemed.no

Heidi Åsheim-Olsen N Nasjonalt senter for samhandling og telemedisin, Norge

heidi.asheim-olsen@telemed.no 



\section{Metode}

I arbeidet med denne rapporten og spørsmålet om nordisk e-resept har vi samlet inn informasjon fra alle de nordiske landene. Dette har vi gjort både gjennom søk på Internett, dokumentstudier (rapporter, offentlige utredninger og artikler) samt studier av lovverk. I «kjølvannet» av etableringen av Nordisk eHelseforum har vi etablert et mer uformelt Nordisk juristnettverk for eHelse. Medlemmer i dette nettverket har bidratt med å kartlegge det juridiske rammeverket.

En sentral del av faktainnsamlingen er en nordisk kartlegging gjennomført i april/mai 2009. Gjennom denne ønsket vi å få en oversikt over elektroniske resepter i de nordiske land: Hva er status? Hvordan er dette organisert i de ulike landene? Hvordan er elektroniske resepter lovregulert? Hva slags teknologi er i bruk?

I tråd med mandat og rammer for Nordisk eHelseforum har vi ikke fokusert på teknologiske løsninger, men vi ble enige om at det ikke var mulig å si noe fornuftig om elektroniske resepter uten i alle fall å ha et overordnet bilde av de ulike teknologiske løsningene. Uansett hvordan man velger å gjøre en eventuell regional løsning må denne ta hensyn også til de valg de enkelte landene har gjort i forhold til teknologien. 



\section{Generelt om elektroniske resepter}

\subsection{Hvorfor gjøre reseptene elektroniske?}

\subsubsection{Innledning}

Argumentene for å gå over fra papir- til elektroniske resepter er i stor grad sammenfallende i alle de nordiske landene, og vi finner dem også igjen i andre land i verden som enten har innført eller vurderer å innføre slike ordninger.

\subsubsection{Moderne informasjonsteknologi i helsevesenet}

En sterk drivkraft for utvikling av elektroniske resepter - i Norden og i mange andre land i Europa og verden - er naturligvis en stadig økende bruk av informasjonsteknologi i helsevesenet som helhet. Begreper som telemedisin og eHelse dekker en hel mengde ulike tjenester, løsninger og kommunikasjonsformer.

Helsevesenet produserer og kommuniserer en enorm mengde informasjon som på ulike vis er en del av det å behandle en pasient. Det er ingen tvil om at moderne informasjonsteknologi kan bidra enormt til bedre og mer effektiv behandling av denne informasjonen. Utskriving, formidling og behandling av resepter og reseptbelagte medikamenter er en viktig del av pasientbehandlingen og en prosess som det er naturlig også å gjøre elektronisk. De aller fleste allmennpraktikere og stadig flere legevakter og sykehus har allerede elektroniske dokumentasjonssystemer (journaler) og mange kan i dag sende ulike meldinger direkte til og fra disse systemene. I mars 2009 ble det sendt ikke mindre enn 4.8 millioner meldinger gjennom det danske sundhedsdatanet, ifølge MedCom ${ }^{1}$. Det er en naturlig videreutvikling av disse systemene og denne kommunikasjonen at også reseptinformasjon kan sendes og mottas elektronisk, uten at det er nødvendig å skrive ut papirresepter.

\footnotetext{
${ }^{1}$ http://www.medcom.dk/wm110885 (28.04.09)
} 


\subsubsection{Reseptkvalitet}

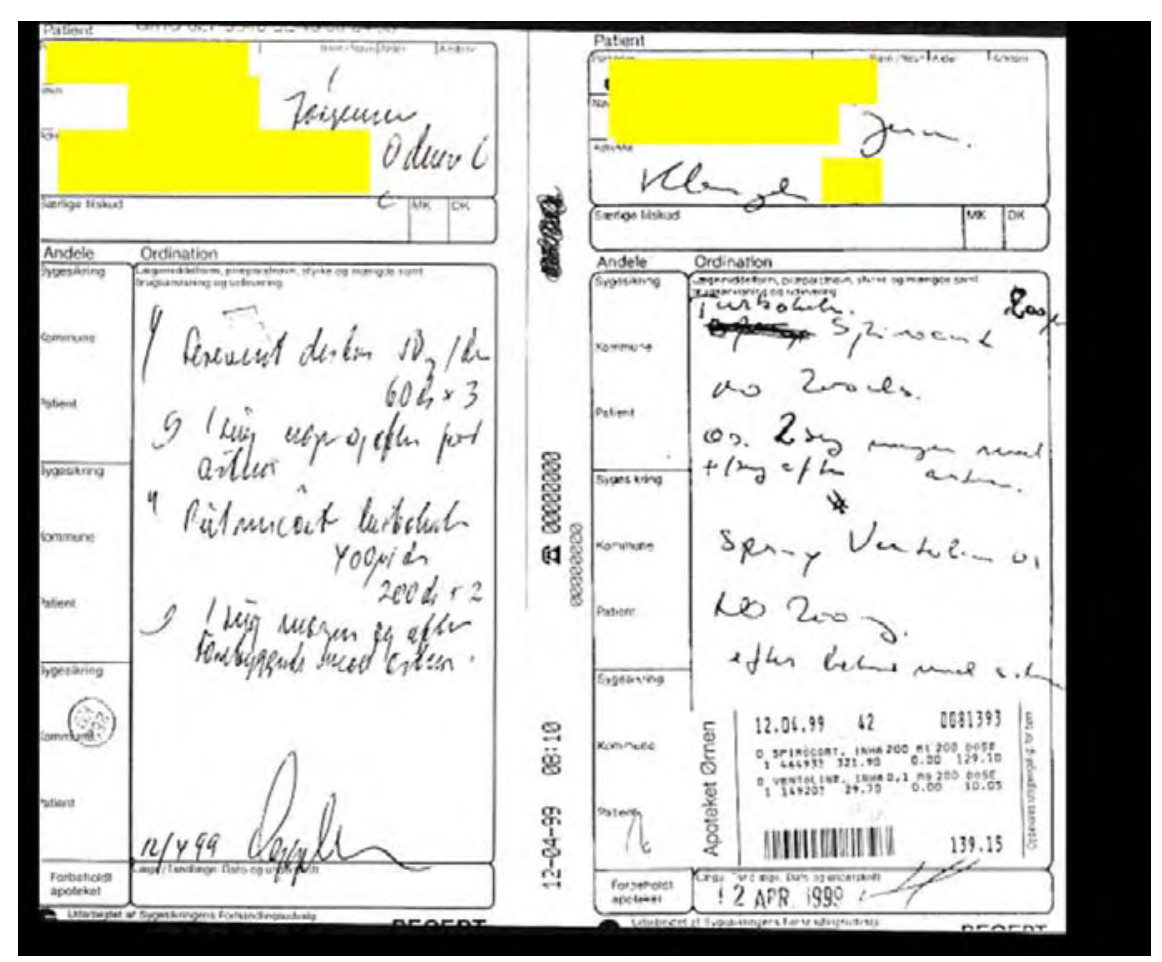

Et viktig argument for innføring av elektroniske resepter er kvalitetssikring. Dette handler ikke bare om det å fjerne usikkerhet og uklarhet knyttet til håndskrevne resepter, men også forhold knyttet til sikker overføring av informasjon fra lege til apotek, såkalt forskrivningsstøtte for legen, samt mer effektiv behandling av reseptene.

\subsubsection{Fordeler for pasienten}

Elektronisk resept medfører store fordeler for pasienten. Hun eller han behøver ikke passe på og holde rede på sine egne resepter. Pasienten kan gå inn på et hvilket som helst apotek og bare ved å legitimere seg få ekspedert sine legemidler.

\subsection{5 Økonomi}

I Norge ble det i 2005 omsatt legemidler etter resept for 14,2 milliarder norske kroner. ${ }^{2}$ Av dette refunderes rundt 8 milliarder av Folketrygden (blåresept). Også i de andre nordiske landene omsettes legemidler for store beløp. Det er naturligvis et stort behov for å ha så god kontroll som mulig med denne omsetningen, ikke minst med den delen som refunderes gjennom landenes trygdeordninger. Flere (de fleste) av e-resptløsningene

\footnotetext{
${ }^{2}$ Ifølge Ot.prp. nr 52 (2006-2007) Om lov om endringer i helseregisterloven (nasjonal database for elektroniske resepter)
} 
er da også knyttet tett opp til de nasjonale ordningene for det økonomiske oppgjøret mellom aktørene.

\subsection{Hva er en elektronisk resept?}

En elektronisk resept er en type elektronisk melding som blir behandlet ${ }^{3}$ ved bruk av moderne informasjons- og kommunikasjonsteknologi, typisk internett-teknologi. Mens den tradisjonelle, papirbaserte, resepten er ett (eller flere) fysisk(e) dokument(er), er ikke dette nødvendigvis tilfelle for den elektroniske resepten. E-resept kan også sies å være betegnelse på en kommunikasjonskjede mellom de aktørene som er inne i bildet når reseptinformasjon behandles. I sin beskrivelse av den norske e-reseptløsningen skriver det norske Helsedirektoratet at disse aktørene inngår i «verdikjeden for eResept ${ }^{4}$ Dette er en beskrivelse vi tror er dekkende for løsningene i alle de nordiske landene.

På et prinsipielt (og konseptuelt) plan er ikke selve den fysiske resepten som er interessant. Papirresepten er bare et dokument som skal sørge for at rett informasjon blir sendt fra rett avsender (legen) til rett mottaker (apoteket). Resepten autoriserer pasienten i den forstand at hun eller han tar denne med seg til apoteket og dermed får rett til å kjøpe det aktuelle medikamentet.

Det samme gjelder naturligvis den elektroniske resepten. Den elektroniske resepten blir summen av det juridiske rammeverket, informasjonssikkerheten, teknologien, infrastrukturen og organisasjonene som skal til for at informasjon om at medikamenter er utskrevet ett sted (hos legen) skal kunne bli tilgjengelig et annet (på apoteket) gjennom bruk av informasjonsteknologi. På et praktisk plan kan det være snakk om oversending av meldinger, tilgang til meldinger, tilgang til journalsystemer, tilgang til egne reseptformidlere, osv.

\subsection{Ulike løsninger for elektronisk resept}

På et praktisk-teknisk plan finnes det mange måter å behandle resepter elektronisk. Som kartleggingen vår viser har da også de nordiske landene valgt til dels ulike systemer og applikasjoner. Hvilken løsning som blir valgt har nok å gjøre med hva slags systemer man har i bruk i dag, hva

\footnotetext{
${ }^{3}$ Begrepet «behandle» defineres i denne rapporten på samme måte som i EUs personverndirektiv (Direktiv 95/46/EC), Article 2 (b): «processing of personal data'('processing') shall mean any operation or set of operations which is performed upon personal data, whether or not by automatic means, such as collection, recording, organization, storage, adaptation or alteration, retrieval, consultation, use, disclosure by transmission, dissemination or otherwise making available, alignment or combination, blocking, erasure or destruction;»

${ }^{4}$ http://www.helsedirektoratet.no/vp/multimedia/archive/00053/Hva_er_e-resept_53709a.pdf (05.05.09)
} 
man ønsker å oppnå med elektroniske resepter og også noen mer overordnede valg og føringer i de ulike landene. 


\section{Elektroniske resepter over landegrensene i Norden - hvorfor?}

\subsection{Innledning}

Selv om alle de nordiske landene har tatt i bruk informasjonsteknologi i helsevesenet i forholdsvis stor skala og herunder tatt i bruk elektroniske resepter er jo ikke dette i seg selv grunn nok til å bruke tid og ressurser på å utvikle en overnasjonal, nordisk løsning. Det er imidlertid gode grunner for at dette ikke bare er noe de nordiske landene kan se nærmere på, men at det er noe vi faktisk må gjøre.

\subsection{Mobilitet og nærhet}

Det er stor grad av mobilitet mellom beboerne i de nordiske landene, både knyttet til turisme og arbeid. Turister fra de andre nordiske landene utgjør en stor del av den totale turiststrømmen i alle de nordiske landene. ${ }^{5}$ Det er også lang tradisjon for utveksling av arbeidstakere mellom mange av de nordiske landene. For eksempel finner man mange både danske og svenske helsearbeidere på norske sykehus.

Mange av de nordiske landene har felles grenser, og til dels store grenseområder. I disse områdene er det lang tradisjon for handel og annen trafikk over grensene. For noen samfunn er det sånn at det er enklere og kortere til et sentrum på den andre siden av grensen enn til et i eget land. På slike steder vil det også være naturlig og enkelt å kunne hente ut medikamenter på apoteket i nabolandet.

Det nordiske samarbeidet handler i stor grad om å fjerne såkalte grensehindringer. Dette inkluderer også hindringer for mobilitet mellom landene. Sikker og effektiv kommunikasjon av helseinformasjon vil bidra til å gjøre det enklere for nordiske borgere både å være turister i de andre nordiske landene og å bo og arbeide der.

\footnotetext{
${ }^{5}$ Se f.eks. http://www.ssb.no/emner/10/11/reiseliv/main.shtml (05.05.09)
} 


\subsection{Lov og avtaler/gjeldende rett}

Siden 1977 har det vært mulig å hente ut medikamenter i ett nordisk land på resepter som er utskrevet i et annet. Ordningen ble etablert på bakgrunn av en nordisk anbefalning og ble deretter innarbeidet i de ulike landenes lovverk. I norsk lovgivning ser bestemmelsen slik ut:

«§ 7-4. Ekspedisjon av nordiske resepter og EØS-resepter

Resept utstedt av lege autorisert i Danmark, Finland, Island og Sverige, samt EØS-leger som nevnt i § 2-1 første ledd bokstav b, kan ekspederes på norsk apotek. Slik resept skal ekspederes i henhold til norske bestemmelser, og må fylle de krav som går fram av kap. 3, 4 og 5. Påføring av Id-nummer, jf. § 4-2 første ledd bokstav b, kreves likevel ikke.

Resept som nevnt i første ledd første punktum omfatter ikke:

a) telefonresept og telefaksresept;

b) resept på legemiddel som ikke har norsk markedsføringstillatelse eller generelt godkjenningsfritak;

c) resept på legemiddel i reseptgruppe A;

d) resept på legemiddel i reseptgruppe B som har vært ekspedert i rekvirentens hjemland;

d) desinfeksjonssprit og varer som hører inn under forskrift om brennevin, herunder spiritus, og vin til medisinsk bruk. ${ }^{1}$

En nordisk resept som har vært ekspedert i rekvirentens hjemland, kan ekspederes én gang ved norsk apotek. Dette gjelder ikke hvis reseptutstederen har påført resepten «non reit» eller annen begrensning for ny ekspedisjon.

Bestemmelsene i denne paragraf gjelder tilsvarende så langt de passer for ekspedisjon av nordiske resepter og EØS-resepter utstedt av tannlege og veterinær.» ${ }^{6}$

Spørsmålet om anerkjennelse av resepter over landegrensene i Norden ble reist allerede i 1954. I den nevnte anbefalingen til de nordiske lands ministre og departementer ble det fremhevet at en slik ordning ville være et naturlig steg i utviklingen av eksisterende nordisk samarbeid på det farmasøytiske området. ${ }^{7}$

Dersom utviklingen av elektroniske resepter går den veien det ser ut til i dag og i tråd med de nordiske lands strategier og planer, vil situasjonen om noen år være den at resepter kun er elektroniske i en eller annen form. Konsekvensen av det er at dersom det nordiske reseptsamarbeidet fortsatt skal ha mening og innhold, må man finne en ordning for ekspedering av elektroniske resepter fra ett nordisk land i et annet.

De nordiske land har lang tradisjon for og erfaring med samarbeid, og dette bør være et godt grunnlag også for et samarbeid om utvikling av en nordisk e-reseptløsning. Norden er en god arena for pilotering av en slik løsning, og et nordisk system for elektroniske resepter kan kanskje være

\footnotetext{
${ }^{6}$ Forskrift om rekvirering og utlevering av legemidler fra apotek, § 7-4.

${ }^{7}$ «Nordic-wide validity of prescriptions», NLN Publication No 47
} 
en innfallsport og en begynnelse på et mer omfattende nordisk helsesamarbeid gjennom økt bruk av informasjonsteknologi.

\section{4. epSOS-prosjektet}

Prosjektet «European Patients Smart Open Services - epSOS» ble startet opp 1. juli 2008. epSOS er et omfattende og ambisiøst prosjekt med 27 partnere fra 12 medlemsland. Av de nordiske landene er Danmark og Sverige deltakere i prosjektet.

Ifølge nettsidene ${ }^{8}$ er prosjektets hovedmål å «...define services for $a$ pan-European electronic patient summary and ePrescription». Dette hovedmålet er ytterligere spesifisert i form av 9 såkalte «specific goals»:

- Agreement on a dataset describing the accepted terms of patient summaries, as well as the minimum data set required for countries to connect to the services;

- Agreement on a basic dataset and other requirements for ePrescriptions;

- Agreement on a minimum set of requirements to access this information taking the needs of the various constituencies, such as citizens, healthcare professionals, and healthcare provider organisations into account;

- Design, implementation and testing of a practical technical solution for confidentiality and security requirements in a 'laboratory' setting;

- Demonstrate the practical implementation of the solution - in compliance with confidentiality and security requirements; in numerous settings as well as participating states

- Evaluation of the results following their practical implementation;

- Demonstration of the ability to access information in compliance with relevant confidentiality and security requirements, in particular including the guidelines of the European Data Protection Directive and any other formally agreed upon amendments based on Article 29 Working Party;

- Selection and usage of relevant interoperability standards.

- Advise on implementation methods, which can be replicated in all other member states

${ }^{8}$ www.epsos.org 
I forhold til vårt arbeid er det naturligvis særlig interessant at prosjektet skal arbeide med spørsmålet om dataset og krav til e-resepter og mer generelt muliggjøre økt interoperabilitet mellom landene i Europa. Prosjektet har en arbeidsplan i 5 punkter:

- Analyse og evaluering

- «The objective of this project work domain is a pan-European analysis of architecture, implementation and all technically relevant features of national solutions.»

- Juridiske aspekter

- «This PD deals with identifying all necessary permissions and regulatory clarifications in each member state (MS).

Recommendations for legal and regulatory change shall be delivered in order to eliminate barriers and facilitate epSOS Systems in participating MS and beyond.»

- Spesifisering og implementering

- «The main goal is to find a definition of the functional service requirements for the epSOS System.»

- Utprøving

- «This PD copes with field testing by, for instance, specifying test scenarios including site choice.»

- Prosjektledelse.

Vi tar med epSOS-prosjeket her fordi dette er et prosjekt som kan få stor betydning for utviklingen av grenseoverskridende helsetjenester i Europa og følgelig også i Norden. Nordisk eHelseforum tror det er viktig og riktig at et eventuelt nordisk initiativ ikke kommer i konflikt med epSOSprosjektet eller blir en konkurrent til dette. Både Sverige og Danmark har knyttet forholdsvis store ressurser til prosjektet og landenes videre utvikling av e-reseptløsninger vil skje innenfor rammene av dette prosjektet.

\subsection{Behov?}

Forarbeidet til ordningen med gjensidig anerkjenning av nordiske resepter ble gjort av en «Nordisk reseptkomité». Denne komiteen la faktisk til grunn at det ikke var noe egentlig behov for nordiske borgere å ha mulighet til å hente ut reseptbelagte medikamenter i andre nordiske land. Komiteen argumenterer blant annet med at syke personer ikke reiser særlig mye og at kronikere vil ha med seg nødvendig medisin når de reiser. I 
alle tilfeller, peker komiteen på, kan en nordisk borger oppsøke lege i et annet nordisk land dersom borgeren skulle få behov for medikamenter.

Antakelig kan vi bruke alle disse innvendingene også når vi snakker om et system for nordisk elektronisk resept.

I rapporten «Nordic-wide validity of prescriptions» (se note over) presenteres en evaluering av ordningen der man blant annet har sett på hvor mange resepter fra de andre nordiske land som håndteres ved apoteker $\mathrm{i}$ Norden. Evalueringen baserer seg på å studere antall preskripsjoner i to uker (ukene 29 og 43). Dersom disse antas å være representative for resten av året tilsier det at det i 1996 ble håndtert omtrent 8600 såkalte nordiske resepter ved apoteker i Norden. I 2008 ble det i Skåne ekspedert rundt 1000 danske resepter. Sammenlignet med det totale antallet er ikke dette særlig mye, men evalueringen viser at antallet har vært jevnt stigende siden 1979.

Evalueringen viser også at selve systemet fungerer uten større problemer selv om det, like etter ordningen ble etablert, oppstod en del uklarheter og spørsmål.

I rapporten pekes det også på at en grunn til at det ikke forskrives mer av det man kan kalle «nordiske resepter» er at ordningen er lite kjent og at $\mathrm{i}$ de fleste tilfeller vil en pasient hente ut medikamenter straks etter et legebesøk og derfor bruke apotek lokalt. I rapporten pekes videre på at mange av de innvendinger man hadde ved innføring av den nordiske reseptordningen ikke slo til eller $\mathrm{i}$ alle fall har vist seg å ikke representere store problemer.

Selv om man kan argumentere for et visst behov for en ordning med godkjenning av resepter i alle land i Norden og at denne ordningen i alle fall har vært nyttig for noen, er det antakelig et behov for å argumentere ytterligere for at man skal utvide de nasjonale e-reseptordningene til et nordisk system. Det må også her være relevant å spørre seg hvor stort behovet virkelig er.

Vi tror at behovet er der, og at det vil være økende. Som vi har nevnt over vil det også være slik at i løpet av de nærmeste årene vil flere og flere - og etter hvert alle - resepter bli behandlet elektronisk i de nordiske landene. Dersom ordningen med nordisk godkjenning av resepter skal ha verdi og noe innhold må man imidlertid finne en løsning for at denne også skal gjelde elektroniske resepter.

Man skal heller ikke se bort fra at behovet faktisk er større enn det man ser i dag. Det kan godt tenkes at informasjon om ordningen vil føre til økt bruk for mange som trenger medikamenter, enten som studenter, arbeidstakere eller turister i Norden.

Borgernes krav og forventninger til helsevesen og helsehjelp endres stadig. Kanskje vil den nordiske «borger-pasienten» om ikke lenge ta det for gitt at hun eller han skal kunne hente ut sine medikamenter på et hvilket som helst apotek i Norden - og antakelig også i resten av Europa. 
Et nordisk system for grenseoverskridende elektroniske resepter vil dessuten kunne bli en modell for lignende ordninger i andre regioner og for kommunikasjon av annen type informasjon både innenfor helse og på andre områder. 


\section{Rammer og utfordringer}

\subsection{Innledning}

Selv om informasjons- og kommunikasjonsteknologi utvilsomt er gode verktøy i helsevesenet er det en rekke utfordringer og problemer knyttet til bruken. Dette gjelder denne teknologien på samme måte som alle andre innovasjoner. I alle de nordiske landene har man erfaring fra det å arbeide med juridiske spørsmål, teknologi og standarder, informasjonsteknologiens innvirkning på organisasjonene, økonomiske konsekvenser, osv, osv. Alle disse temaene «tar man med seg» når man ønsker å tilby helsetjenester også utenfor rammen av en enkelt stat og mellom ulike stater, i tillegg til at slike «grenseoverskridende» tjenester utløser nye utfordringer og skaper andre problemer.

\subsection{Juridiske forhold}

Som før nevnt har alle de nordiske landene omfattende lovverk på områdene helse og informasjonsbehandling. Enhver løsning, ethvert system og enhver tjeneste som skal «operere» på området helsehjelp og behandling av potensielt sensitiv pasientinformasjon, må forholde seg til det juridiske rammeverket og tilpasse sin løsning det rammeverk som gjelder. Dette gjelder på nasjonalt plan og om man betrakter de juridiske forholdene som utfordringer, og kanskje også barrierer, så blir ikke disse mindre når den aktuelle løsningen eller tjenesten skal foregå på tvers av landegrenser. I forhold til tanken om nordisk elektronisk reseptløsning, som med mange andre e-helseløsninger, har det blitt sagt at det nok er mulig å få til gode og effektive teknologiske løsninger. Problemet er å få disse til å fungere innenfor lovverket. Det er mulig dette er riktig. Uansett er det viktig å ha kjenneskap til hva slags utfordringer dette er - eller kan være.

I Norden har man også erfaring for samarbeid om lovverk med sikte på å lette samarbeid mellom landene. Ordningen med nordisk godkjenning av resepter er et eksempel på dette. Det er forumets oppfatning at likhetene mellom de nordiske lovverkene, tradisjoner for samarbeid og vilje til å gjøre nødvendige tilpasninger, tilsier at alle forutsetninger er til stede for at det skal være mulig å få til et nordisk e-reseptsystem innenfor rammene av gjeldende lovverk. Det er likevel noen overordnede hensyn og føringer som vi mener må være til stede for at man skal få til en harmonisering av lovverkene i de nordiske landene: 


\subsubsection{Sikker informasjonsbehandling}

Taushetsplikt og konfidensialitet er helt sentrale elementer i kommunikasjonen og samarbeidet mellom helsepersonellet og pasienten. All helseinformasjon er sensitiv og skal behandles deretter. Reseptinformasjon er naturligvis ikke noe unntak. Alle de nasjonale lovverkene understreker plikten til å bevare taushet, og dette er både regnet som en plikt for det enkelte helsepersonell, en rettighet for den enkelte pasient og et ansvar for de som eier og driver helseinstitusjoner (systemansvar).

Det å behandle helseinformasjon på en forsvarlig og riktig måte er en del av de krav man stiller til at helsepersonell skal utføre sitt arbeid på en forsvarlig og profesjonell måte.

Innføring av informasjonsteknologi i helsevesenet representerer fortsatt til dels store utfordringer når det gjelder det å få nye løsninger til å fungere innenfor gjeldende lovverk. Det er mye man ser at det er mulig å gjøre på svært effektive og elegante måter ved hjelp av informasjonsteknologien, men som det ikke er mulig å gjøre fordi lovverket «står i veien». Slik vil det antakelig alltid være. I forhold til elektroniske resepter over landegrensene er det etter vår oppfatning viktig å ha dette klart for seg og alltid forholde seg til at mulige løsninger ikke må være i strid med nasjonale lovverk og internasjonalt regelverk, for eksempel innen EU. Det betyr at krav til informasjonssikkerhet må oppfylles og at prinsipper for behandling av personopplysninger må ivaretas.

\subsubsection{Pasientrettigheter}

Pasientrettighetene står sterkt i alle de nordiske land. Finland var det første land i verden som vedtok en egen lov om pasientrettigheter. Senere har flere land fulgt etter, blant annet mange av de nordiske.

De spesifikke rettighetene vil variere noe mellom de ulike land, men det er noen som vi ser er mer eller mindre felles for alle.

Samtykke er sentralt. All undersøkelse og behandling av en pasient skal være basert på samtykke, også behandling i form av forskrivning av medikamenter. I praksis og i de langt fleste tilfeller er ikke dette noe problem. Pasienter som oppsøker lege for en lidelse eller et problem, ønsker jo behandling og dersom denne behandlingen er i form av medikamenter vil jo pasienten samtykke til det.

Samtykke er også et sentralt grunnlag for behandling av personopplysninger. Personopplysningsdirektivet og tilhørende nasjonal lovgivning etablerer en praksis hvor samtykke i utgangpunktet skal være grunnlag for all behandling av personopplysninger - elektronisk eller manuelt. Imidlertid gir direktivet mulighet til å behandle opplysninger uten samtykke men med hjemmel i lov. Det er slik de nordiske (nasjonale) ereseptløsningene er lovregulert. Det er ikke nødvendig å innhente samtykke fra pasienten for å kunne behandle reseptinformasjon elektronisk. 


\subsection{EU-rett}

På området helse er EUs kompetanse i forhold til direkte lovgivning begrenset. Administrering og regulering av helsehjelp er i utgangspunktet helt og fullt den enkelte medlemsstats ansvar. Det er likevel områder der EUs lovgivning og -reguleringer får eller kan få betydning for helse og landenes måter å yte helsetjenester på.

\subsubsection{Behandling av informasjon}

Vi har allerede nevnt EUs direktiv om behandling av personlige data (se note over). Direktivet slår fast en rekke prinsipper for behandling av personopplysninger, både helseinformasjon og annen informasjon og både ved elektroniske og manuelle registre. Medlemsstatene og landene i EØSområdet har gjort bestemmelsene i direktivet til nasjonal lov gjennom egen personvernlovgivning og for noen lands vedkommende også egen lovgivning om behandling av helseinformasjon ${ }^{9}$.

Innenfor feltet telemedisin og eHelse har Direktivet og nasjonal lovgivning stor betydning i forhold til å sette rammer for og krav til måten helsepersonell og helseforetak kan og skal behandle helseinformasjon.

Personverndirektivet etablerer også et prinsipp om at personopplysninger kan utveksles mellom medlemslandene. Direktivets ordning er at landene som etterlever direktivets prinsipper og regler har en tilstrekkelig grad av sikker behandling av personopplysninger til at slik overføring og utveksling kan skje. Data kan også overføres til tredjeland dersom disse godtgjør en tilstrekkelig grad av informasjonssikkerhet.

\subsubsection{Tjenesteyting}

Helsetjenester kan falle inn under området for EUs tjenestedirektiv med tilhørende nasjonale lovbestemmelser. Apotektjenester kan også tenkes å komme inn under området for direktivet. Vi har ikke gjort en nærmere analyse av dette.

\subsubsection{Direktiv om grenseoverskridende helsetjenester}

I skrivende stund er kommisjonen i ferd med å utarbeide og få inn høring på et forslag til et direktiv for «...safe, high-quality and efficient crossborder healthcare.» ${ }^{10}$ Hovedpunktene i forslaget til direktiv er ${ }^{11}$ :

\footnotetext{
${ }^{9}$ Se for eksempel Norges «Lov om helseregistre og behandling av helseopplysninger» av 18. mai $2001 \mathrm{nr} 24$ (http://www.lovdata.no/all/hl-20010518-024.html)

${ }^{10}$ http://ec.europa.eu/health/ph_overview/co_operation/healthcare/docs/COM_en.pdf (29.05.09)

${ }^{11}$ Hentet fra Nyhetsbrev for Arbeidsgiverforeningen Spekter, Helse i EU/EØS - oktober 2007. http://www.spekter.no/FindInMenu.asp?I=3259\&C=661\&D=2_(29.05.09)
} 
Helsetjenester: Mobile pasienter skal kunne motta helsetjenester i et annet EU-land på linje med det de har rett til i hjemlandet. Medlemsstatene skal sikre kvalitet og sikkerhetsstandard i henhold til dette.

Kostnader: $\quad$ Pasientenes hjemland skal dekke kostnadene for helsetjenester i utlandet inntil prisen de ville ha betalt om pasienten ble behandlet $\mathrm{i}$ hjemlandet.

Godkjenning: $\quad$ Pasienter trenger godkjenning på forhånd før de oppsøker medisinsk behandling i utlandet, men de kan ikke nektes behandling dersom det anses som «nødvendig» (appropriate).

Informasjon: $\quad$ EU-landene skal sørge for all relevant informasjon slik at pasientene kan foreta informerte valg. Pasientene må få informasjon om tilgjengelighet, priser og resultat av helsetjenesten de tilbys. Det må også etableres prosedyrer for hvordan eventuelle feilbehandlinger skal håndteres.

Samarbeid: $\quad$ EU-landene skal samarbeide om blant annet telemedisinske tjenester for å sikre utveksling av pasientdata over landegrensene, men samtidig sikre personvernet.

Forslaget diskuterer både ehelse og elektroniske resepter. I innledningen (avsnitt 8.4) vises det til landenes økende bruk av ehelseløsninger og at på grunn av disse er det ikke lengre alltid nødvendig hverken for helsepersonell eller pasienter å fysisk flytte seg fra ett land til et annet. Det pekes på at en grunn til at slike tjenester er vanskelig å få til over landegrensene er ulike standarder, tjenester, løsninger og manglende såkalt interoperabilitet. I forslaget fremheves likevel at «...the proposal does not oblige any introduction of e-health systems or services but aims at ensuring interoperability once the choice of introducing such systems is done by Member States.»

I forslaget er eHelse gitt en egen artikke, Artikkel 16. Bestemmelsen pålegger kommisjonen å sette i verk tiltak for å sikre interoperabilitet over landegrensene for informasjons- og kommunikasjonsteknologi på helseområdet.

Forslaget stadfester et viktig og relevant prinsipp angående betaling. Pasienter skal kunne motta helsehjelp i andre medlemsland og deretter kunne kreve dekket utgiftene til denne helsehjelpen fra sitt hjemlands 
helseforsikring. Prinsippet er at pasientens utgifter skal kunne dekkes opp til det det ville kostet å behandle pasienten i hjemlandet.

Forslaget etablerer en ordning med gjensidig godkjenning av resepter blant medlemeslandene. Denne ordningen er i funksjon allerede i dag.

Etter definisjonen i forslagets Artikkel 4 omfatter definisjonen av resept også e-resept.

En viktig bestemmelse er foreslått i Artikkel 14:

«2. For facilitating the implementation of paragraph 1, the Commission shall adopt:

(a) measures enabling a pharmacist or other health professional to verify the authenticity of the prescription and whether the prescription was issued in another Member State by an authorised person through developing a Community prescription template, and supporting interoperability of ePrescriptions;»

En slik bestemmelse vil kunne få direkte betydning både for implementering og utvikling av nasjonale løsninger og for etablering av løsninger over landegrensene - i Norden og i resten av Europa.

Forslaget til direktiv blir fortsatt diskutert og man har fortsatt ikke kommet til enighet. Det er en rekke spørsmål og problemstillinger som reises fra ulike land, og mange av disse angår naturligvis nettopp hvordan man skal sikre pasientenes sikkerhet og personvern. ${ }^{12}$

\subsection{Teknologi - generelt}

I vårt arbeid har vi ikke hatt spesielt fokus på teknologi og mulige teknologiske løsninger. Vi ser imidlertid klart at dette er et viktig tema og at det ikke vil være mulig å komme videre i arbeidet med en nordisk ereseptløsning uten å arbeide med teknologiske utfordringer og muligheter fra starten av.

Utviklingen av telemedisin og eHelse er jo, i alle fall tradisjonelt, teknologidrevet. Erfaringen er at teknologien sjelden er problemet. Det er andre forhold og rammer som er, eller oppleves som, begrensninger og barrierer for utviklingen.

I 2008 startet epSOS-prosjektet opp ${ }^{13}$. Prosjektet er delvis EU-finansiert og har 27 deltakere fra 12 medlemsland - deriblant flere av de nordiske landene. Prosjektet er interessant for vårt arbeid fordi det blant annet skal teste ut en teknologisk løsning for såkalt «patient summary» og også «electronic prescription». Se nærmere om prosjektet i pkt 6.3 nedenfor.

\footnotetext{
${ }^{12}$ http://www.eahp.eu/EAHP-EU-Monitor/No-consensus-on-the-Patients-Rights-to-CrossBorder-healthcare-found-yet (29.05.09).

${ }^{13}$ http://www.epsos.eu/epsos-home.html (26.05.09)
} 


\subsection{Informasjonssikkerhet}

Reseptinformasjon inneholder sensitive helseopplysninger og skal som sådan behandles konfidensielt. Beskyttelse av helseopplysninger er sentralt i alle lands lovverk, og innføring av informasjonsteknologi gjør ikke behovet for beskyttelse mindre. Begrepet informasjonssikkerhet brukes gjerne om det sett av tekniske og organisatoriske løsninger og rutiner som i sum skal sikre at informasjon behandles på en slik måte at krav i lovgivningen ivaretas. Dette dreier seg ikke bare om krav til konfidensialitet og ivaretakelse av taushetsplikt. Begrepet informasjonssikkerhet sies ofte å skulle ivareta disse hensynene:

- Konfidensialitet

- I helsevesenet er det her snakk om å ha systemer som sikrer og ivaretar helsepersonellets lovpålagte taushetsplikt og pasientenes rett til å få sine opplysninger behandlet konfidensielt.

- Integritet

- Sikre at informasjonen ikke endres eller slettes på en uautorisert måte. Det skal være sikkerhet for at den informasjonen som hentes ut av et system er den samme som den som ble lagt inn.

- Tilgjengelighet

- Informasjonssikkerhet handler også om at informasjonen skal være tilgjengelig for den som har krav på informasjonen når vedkommende har slikt krav. Dette er særlig viktig i helsevesenet der tilgjengelighet til rett informasjon til rett tid er avgjørende for å sikre godt pasientbehandling.

- Kvalitet

- Man inkluderer gjerne også kvalitet i begrepet informasjonssikkerhet. Tekniske løsninger skal være slik at de sikrer at informasjonen lagres på en måte som ivaretar kvaliteten. Dette vil særlig være aktuelt for visuell informasjon, for eksempel ved bruk av digitale røntgensystemer.

Alle de nordiske landene har personvernlovgivning som i stor grad er i tråd med ordninger og retningslinjer i EUs personverndirektiv ${ }^{14}$. Dette innebærer blant annet at det $\mathrm{i}$ henhold til direktivet og de nordiske lands lover er tillatt å overføre også sensitiv informasjon mellom land. Direktivet (og lovverkene) legger til grunn en ordning der land som har sluttet seg til direktivet forutsettes å ha et tilstrekkelig godt nivå på informasjonssikkerheten til at informasjon kan sendes mellom disse landene. I forhold til en nordisk løsning for e-resept er dette naturligvis en stor fordel.

\footnotetext{
${ }^{14}$ Directive 95/46/EC of the European Parliament and of the Council of 24 October 1995 on the protection of individuals with regard to the processing of personal data and on the free movement of such data
} 


\subsection{Identifikasjon}

I forhold til resepter og reseptinformasjon er identifikasjon viktig. Det er flere parter som skal identifiseres i løpet av den prosessen (eller «verdikjeden») som behandling av en resept er.

\subsubsection{Helsepersonell}

For det første krever alle de nordiske lands lovverk at forskrivende lege skal være identifisert på resepten - også når resepten er elektronisk. Rett til å skrive ut resept følger gjerne autorisasjon som lege, tannlege eller veterinær. De enkelte land gir autorisasjon til sitt helsepersonell og registrerer disse i sine registre. Det foreligger ikke noe felles nordisk helsepersonellregister og det er heller ikke uten videre mulig å søke opp helsepersonell i de ulike landenes registre.

Uansett valg av en felles nordisk løsning, må man ha på plass systemer og rutiner for sikker identifikasjon av den som skriver ut resepten. Dette både for å sikre at vedkommende er autorisert til å skrive ut resept og for å sikre reseptkvaliteten.

\subsubsection{Pasienter}

For å sikre at rett medikament kommer til rett person er det avgjørende viktig at pasienten - den som skal få ut medikamentene - kan identifiseres på en sikker og pålitelig måte.

Nasjonalt er som regel dette ikke noe problem. Alle land har en eller annen form for pasientidentifikasjon. I Danmark har man såkalte CPRnumre, i Norge benyttes et 11-sifret fødselsnummer som er unikt for hver borger. Disse systemene er ulike i de respektive land. Imidlertid vil man nok som regel kunne løse dette problemet ved at det etableres rutiner i de nordiske land for å undersøke identifikasjonspapirene til den som kommer for å få medikamenter utlevert. Dennes ID må enkelt kunne kontrolleres opp mot den pasientidentifikasjonen som forskrivende lege vil «skrive» på resepten.

\subsubsection{Apotek}

Også det apotek som leverer ut reseptbelagte medikamenter skal identifiseres. Denne identifikasjonen kan antakelig gjøres forholdsvis enkelt ved å benytte apotekets navn og adresse. 


\subsection{Informasjonsutveksling}

Uansett valg av løsning må nordisk elektroniske resept, på samme måte som de nasjonale løsningene, baseres på et system for utveksling av informasjon mellom lege og pasient og eventuelt også pasienten. Dette er naturligvis kjernen i de nasjonale systemene og må være det $\mathrm{i}$ et felles nordisk system. Noen stikkord knyttet til informasjonsutvekslingen vil være:

- Bare relevant og nødvendig informasjon skal utveksles

- Informasjonsutvekslingen må være sikker

- Pasienten skal kunne få opplyst hva slags informasjon som utveksles og mellom hvem

- Informasjonen må være sikret mot uautorisert tilgang og uautorisert sletting, fjerning eller endring

- Informasjonen må være i et slikt format at den informasjon som legges inn av avsenderen er lesbar for mottakeren.

Som man vil se er alt dette utfordringer som er i kjernen av hele spørsmålet om hvordan man skal få til utveksling av elektroniske resepter mellom de nordiske landene. Dette er spørsmål som både berører de organisatoriske, tekniske og juridiske sidene av en slik løsning.

\subsection{Standardiserte resepter}

Det foreligger nasjonale reseptstandarder i alle de nordiske land og med innføringen av e-reseptsystemer har man også fått standarder knyttet til dette. Vi snakker her både om standarder for utfylling av e-resepten altså hva slags informasjon som skal inn osv, og standarder for ivaretakelse av informasjonssikkerhet.

Vi kjenner ikke til at det finnes en felles nordisk standard for resepter. Imidlertid er det lang tradisjon for samarbeid både på nordisk og europeisk nivå, også på legemiddelsektoren. Ved utredning av en nordisk ereseptløsning bør det vurderes om det er behov for ytterligere samordning og standardisering av resepter både med hensyn til utforming, utfylling, behandling og sikring.

\subsection{Betalingsordninger}

Som nevnt over er en viktig begrunnelse for det å gå over til elektroniske resepter nasjonalt å få kontroll med offentlige utgifter knyttet til reseptbelagt medisin. Dette må også tas hensyn til i en nordisk løsning. 
Medisiner som pasienten skal betale helt ut selv vil normalt ikke være et problem. Da vil pasienten gjøre opp for medikamentene ved utlevering. Noe annet er det dersom pasienten har rett til medikamenter som hun/han ikke skal betale for eller bare skal betale en mindre egenandel for. I Norge sier man gjerne at slike medisiner skrives ut på blå resept. ${ }^{15}$ Det er særlig kronikere som får rett til å få utskrevet medikamenter på blå resept. I forbindelse med en eventuell nordisk løsning for e-resept bør det også ses på hvordan denne type resepter kan og skal behandles.

Ifølge ordningen i Norge er det et vilkår for å få utlevert medikamenter på blå resept er det et vilkår at resepten er utformet i henhold til norske regler om refusjon. Etter dette kan ikke resept utskrevet i et annet nordisk land gi rett til refusjon (se kartleggingen). Det er ikke klart om dette også vil gjelde tilfellet der medikamenter på blå resept hentes ut ved et apotek $\mathrm{i}$ et annet nordisk land. I et slikt tilfelle er det mulig pasienten i første omgang må betale full pris for medikamentene for deretter å søke refusjon fra trygdeordningen i Norge.

\subsection{Andre organisatoriske forhold}

Med andre organisatoriske forhold mener vi her mer generelle utfordringer som ikke direkte er juridiske eller teknologiske og som kan tenkes å ha betydning for etablering av en nordisk e-reseptløsning.

Spørsmålet om hvor og hvordan e-reseptordningene er organisert i de ulike land tror vi først og fremst har betydning i forhold til at man er nødt til å ta ulike interessenter («stakeholders») med også i utviklingen av en nordisk løsning. Kartleggingen vår har vist at det er et forholdsvis stort antall enheter, etater, departementet og andre organer som spiller ulike roller i forhold til håndtering av resepter. Disse må identifiseres, rollene deres må avklares og de må tas med i en eventuell prosess i retning av etablering av en felles nordisk e-resept.

\subsubsection{Interessenter}

I tabellen under har vi listet opp noen av de meste sentrale aktørene eller interessentene som har noe å gjøre med behandling av reseptinformasjon.

\footnotetext{
${ }^{15}$ http://www.nav.no/Helsetjenester/Medisiner/ Bl \%C3 \%A5+resept;jsessionid=B24383A46FACF4571E3BF9394B2E1DEE.navnode02 (07.05.09)
} 


\begin{tabular}{|c|c|}
\hline Interessent & Rolle/oppgave \\
\hline Apoteket AB, SE & $\begin{array}{l}\text { «Eier» } \\
\text { Databehandlingsansvarlig }\end{array}$ \\
\hline Datainspektionen, SE & $\begin{array}{l}\text { Rådgivning } \\
\text { Tilsyn etter personvernlovgivningen } \\
\text { Lovverk }\end{array}$ \\
\hline Tilståndshavaren, SE & $\begin{array}{l}\text { Den som har fått tillatelse til å drive handel med medikamenter. } \\
\text { Databehandlingsansvarlig }\end{array}$ \\
\hline Vårdgivaren, SE & $\begin{array}{l}\text { Skriver ut resepter. } \\
\text { Databehandlingsansvarlig }\end{array}$ \\
\hline Socialstyrelsen, SE & $\begin{array}{l}\text { Tilsyn etter helselovgivningen. } \\
\text { Rådgivning. }\end{array}$ \\
\hline Läkemedelsverket, SE & Tilsyn etter legemiddellovgivningen \\
\hline $\begin{array}{l}\text { Tandvårds- och läkemedelsför- } \\
\text { månsverket, SE }\end{array}$ & Tilsyn etter lov om läkemedelsförmåner m.m. \\
\hline Helsedirektoratet, NO & $\begin{array}{l}\text { «Eier» } \\
\text { Tilsyn } \\
\text { Forvaltning av lovverk } \\
\text { Prosjektleder }\end{array}$ \\
\hline Datatilsynet, NO & Tilsyn etter personvernlovgivningen \\
\hline Helsetilsynet, NO & Tilsyn etter helselovgivningen \\
\hline Legemiddelverket, NO & \\
\hline Folketrygden/NAV, NO & Betalingsordninger (blå resept m.m.) \\
\hline $\begin{array}{l}\text { Hälsoministeriet, IS } \\
\text { Datainspektionen, IS } \\
\text { (http://www.personuvernd.is/) }\end{array}$ & $\begin{array}{l}\text { Forvaltning av lovverk } \\
\text { Godkjenning } \\
\text { Tilsyn }\end{array}$ \\
\hline $\begin{array}{l}\text { Hälsodirektoratet, Landlækni- } \\
\text { sembættið, IS }\end{array}$ & $\begin{array}{l}\text { Ansvarlig for drift av e-reseptsystemet } \\
\text { Forvaltning av lovverk } \\
\text { Tilsyn }\end{array}$ \\
\hline Trygdekassen, IS & \\
\hline Lægemiddelstyrelsen, DK & $\begin{array}{l}\text { Ansvarlig for drift av tjenesten } \\
\text { Dataansvarlig }\end{array}$ \\
\hline Sundhedsstyrelsen, DK & $\begin{array}{l}\text { Tilsyn } \\
\text { Forvaltning av lovverk }\end{array}$ \\
\hline MedCom, DK & Standarder \\
\hline Datatilsynet, DK & $\begin{array}{l}\text { Lovverk } \\
\text { Tilsyn }\end{array}$ \\
\hline
\end{tabular}

Listen er sikkert ikke uttømmende, men viser at det er nødvendig å involvere en hel rekke aktører som har viktige roller og posisjoner i forhold til ulike sider/deler av den prosessen som reseptbehandling utgjør. I tabellen har vi jo heller ikke tatt med to helt sentrale aktører: Apotekene og pasientene. Også disse må naturligvis involveres i et arbeid med et felles nordisk system. 


\section{Elektronisk resept i de nordiske land - kartlegging}

\subsection{Innledning}

I alle de nordiske landene har informasjonsteknologi forlengst gjort sitt inntog i helsevesenet. Alle landene har i flere år arbeidet med telemedisinske løsninger og i de fleste er for eksempel elektroniske journaler utbredt.

Elektroniske resepter er på ulike stadier av utviklingen i de ulike landene. Sverige har tatt slike i bruk for mange år siden og arbeider nå med neste generasjons løsninger der blant annet får mulighet til å lagre reseptinformasjon. I Norge er lovverk og organisasjon på plass og teknologisk løsning valgt. I skrivende stund (mai/juni 2009) har man begynt å prøve ut løsningen i større skala.

I dette kapitelet skal vi forsøke å presentere status for planlegging, innføring og implementering av elektroniske resepter i de nordiske landene. Dette kapittelet er i stor grad basert på den nordiske kartleggingen som e-helseforumet gjennomførte april-mai 2009. Kartleggingen ble gjennomført ved at vi sendte ut et skjema til medlemmene av Nordisk eHelseforum og Nordisk juristnettverk for eHelse med et utvalg punkter og spørsmål som vi ba om en nærmere beskrivelse av. Dette var spørsmål og problemstillinger som vi antar vil være sentrale å undersøke og avklare for å få til en ordning med formidling av reseptinformasjon over landegrensene. Spørsmålene ble forsøkte sortert etter kategoriene:

- Status

- Juridiske problemstillinger

- Organisatoriske spørsmål

- Betaling/økonomi

- Teknologiske løsninger

På de følgende sidene har vi satt sammen noen av svarene vi fikk inn i en tabell slik at det skal være mulig å gjøre en viss sammenligning mellom landene. Kartleggingsskjemaet finnes i vedlegg 2 


\begin{tabular}{|c|c|c|c|c|c|}
\hline & Island & Danmark & Sverige & Finland & Norge \\
\hline Status & $\begin{array}{l}\text { Införing av e-Recept har varit på } \\
\text { gång de senaste par åren. I början } \\
\text { av } 2008 \text { började den största recept } \\
\text { skrivaren, huvudstadens hälsovård, } \\
\text { skicka e-Recept och det var det } \\
\text { stora steget. Nu skickas nästan alla } \\
\text { recept från hälsovården i landet } \\
\text { elektroniskt och en del av sjukhu- } \\
\text { sens recept också. Dom största } \\
\text { utgivarna av recepter som återstår } \\
\text { är privatklinikerna. Man räknar med } \\
\text { att just nu skickas nära } 30 \% \text { av } \\
\text { alla recept elektronisk. } \\
\text { Målet med e-Recepter är att året } \\
2012 \text { blir över } 90 \% \text { av alla recep- } \\
\text { ter, e-Recepter. }\end{array}$ & $\begin{array}{l}\text { Idag er } 50 \text { \% af alle recepter } \\
\text { elektroniske. } \\
\text { Lægemiddelstyrelsen har udviklet } \\
\text { et system (Medicinprofilen), hvor } \\
\text { vi kan modtage e-recepter til } \\
\text { behandling og udlevering på } \\
\text { apotekerne. } \\
\text { Ligeledes registreres køb af læ- } \\
\text { gemidler på recept, både for e- } \\
\text { recepter og for papir-recepter. } \\
\text { Derved samles alle oplysning-erne } \\
\text { om en borgers individuelle læge- } \\
\text { middel-forbrug i dennes personlige } \\
\text { Medicinprofil, således der både } \\
\text { fremgår åbne/delvist åbne e- } \\
\text { recepter, afsluttede e-recepter og } \\
\text { ekspederede papirordinationer, } \\
\text { samt alle køb af lægemidler på } \\
\text { recept. } \\
\text { Alle ordinations- og receptkøb- } \\
\text { plysningerne slettes efter } 2 \text { år. }\end{array}$ & $\begin{array}{l}\text { E-resept innført over hele landet } \\
\text { Over } 75 \% \text { av alle resepter er } \\
\text { elektroniske. }\end{array}$ & $\begin{array}{l}\text { eResept pilot 2002-2006 } \\
\text { Implementering fra tidlig } 2009 \text {. } \\
\text { Full sammenkobling av enheter i } \\
2011 .\end{array}$ & $\begin{array}{l}\text { Versjon } 1 \text { av eResept er pilotert i } \\
\text { liten skala. } \\
\text { Versjon } 2 \text { av eResept er under } \\
\text { utvikling, og bredding er planlagt } \\
\text { fra } 1 \text { halvår } 2010 .\end{array}$ \\
\hline Mål og formål & $\begin{array}{l}\text { Säkrare handling med recepter } \\
\text { Säkrare och förhindra överförbruk } \\
\text { av läkelmedel. } \\
\text { Styrka komplience. } \\
\text { Uppfodra till förnuftig bruk af } \\
\text { läkelmedel. } \\
\text { Effektiv kontroll (för patienten, } \\
\text { apoteket och Myndigheter ). }\end{array}$ & $\begin{array}{l}\text { Lægemiddelstyrelsen har udviklet } \\
\text { et elektronisk register over både } \\
\text { ordina-tioner og de enkelte medi- } \\
\text { cin-brugeres køb m.v. af læge- } \\
\text { midler samt hertil knyttede oplys- } \\
\text { ninger. Stystemet kaldes de } \\
\text { personlige elektroniske medicin- } \\
\text { profiler/Medicinpro-filen. } \\
\text { Man ønskede hermed at skabe et } \\
\text { redskab, der kunne øge funktio- } \\
\text { naliteten i arbejdet for en bedre } \\
\text { kvalitet og sikkerhed i de forskel- } \\
\text { lige led i lægemiddelbehandlingen } \\
\text { - herunder en rationel ordinati- } \\
\text { onspraksis. }\end{array}$ & $\begin{array}{l}\text { Effektivt, bekvämt för patienten, } \\
\text { som kan vända sig till valfritt } \\
\text { apotek. } \\
\text { Öka säkerheten, t.ex. minska } \\
\text { riskerna för förvanskning av re- } \\
\text { ceptet. } \\
\text { Effektiviserar vardagen för för- } \\
\text { skrivarna. Enligt skattning sparas } \\
\text { 15-30 min per dag o förskrivare. }\end{array}$ & & $\begin{array}{l}\text { Formålet med Reseptformidleren } \\
\text { skal være å sikre trygg og effektiv } \\
\text { formidling av reseptinformasjon } \\
\text { mellom aktører som har et legitimt } \\
\text { og tjenstlig behov for slik informa- } \\
\text { sjon, for å sikre pasienten forsvar- } \\
\text { lig og effektiv helsehjelp. Elektro- } \\
\text { nisk formidling av resept og re- } \\
\text { septinformasjon vil bidra til sikrere } \\
\text { og mer effektiv legemiddel- } \\
\text { håndtering, og dermed riktigere } \\
\text { legemiddelbruk for pasienten. } \\
\text { Samtidig sikrer Reseptformidleren } \\
\text { pasientens rett til fritt apotek- og } \\
\text { bandasjistvalg. } \\
\text { Utover dette inneholder eResept- } \\
\text { løsningen oppdaterte opplysninger } \\
\text { om legemidler o.a. fra Legemid- } \\
\text { delverket, som blir tilgjengelig for } \\
\text { legen ved forskrivningen (FEST) } \\
\text { noe som skal heve kvaliteten. }\end{array}$ \\
\hline
\end{tabular}




\begin{tabular}{|c|c|c|c|c|c|}
\hline & Island & Danmark & Sverige & Finland & Norge \\
\hline $\begin{array}{l}\text { Type opplysning- } \\
\text { er som innhentes/ } \\
\text { behandles }\end{array}$ & $\begin{array}{l}\text { Patientens namn, adress } \\
\text { Patientens personnummer } \\
\text { Läkemedels namn, form, styrke, } \\
\text { mängd och dosering. } \\
\text { Läkarens namn och nummer. }\end{array}$ & $\begin{array}{l}\text { Ordinations- og receptkøbs- } \\
\text { oplysninger. } \\
\text { Oplysninger om den ordinerende } \\
\text { læge. }\end{array}$ & $\begin{array}{l}\text { Patientens namn och person- } \\
\text { nummer alt födelsedata och kön } \\
\text { Patientens adress i vissa fall } \\
\text { Läkemedels namn form styrka } \\
\text { mängd och dosering } \\
\text { Förskrivande läkare, adress o } \\
\text { telnr } \\
\text { Dato og utskrivende apotek } \\
\text { Eventuelle endringer. }\end{array}$ & & $\begin{array}{l}\text { Hvilke opplysninger som skal } \\
\text { registreres er bestemt i Resept- } \\
\text { formidler-forskriften § 1-7 (jfr } \\
\text { forskrift om legemidler fra apotek). } \\
\text { Eksempler: } \\
\text { Navn på utsteder } \\
\text { ID-nummer (ihht helsepersonellre- } \\
\text { gisteret) } \\
\text { Opplysninger om pasienten } \\
\text { Navn } \\
\text { Kjønn } \\
\text { F.nummer } \\
\text { Adresse } \\
\text { Opplysninger om legemidlet } \\
\text { Opplysninger om bruk av legemid- } \\
\text { let. }\end{array}$ \\
\hline $\begin{array}{l}\text { Hjemmel for } \\
\text { innsamling av } \\
\text { opplysninger }\end{array}$ & $\begin{array}{l}\text { Lag om medicin nr. 93/1994 och } \\
\text { förodrning nr. nr. 111/2001 om } \\
\text { recepter. } \\
\text { Ny lov om elektronisk journal. }\end{array}$ & $\begin{array}{l}\text { Sundhedsloven og i bekendtgørel- } \\
\text { sen om Lægemiddelstyrelsens } \\
\text { register over Personlige Elektroni- } \\
\text { ske Medicinprofiler (Medicinprofi- } \\
\text { len) }\end{array}$ & $\begin{array}{l}\text { Lov om Receptregister } \\
\text { (1996:1156). } \\
\text { Personuppgiftslagen (1998:208) } \\
\text { Lovendring 1. juli } 2009 \text { (Apoteks- } \\
\text { datalagen, receptregisterlagen og } \\
\text { personuppgift-lagen). }\end{array}$ & Egen lovgivning siden april 2007. & $\begin{array}{l}\text { Stortinget har ved endring av } \\
\text { helse-registerloven } \S 8,3 \text {. ledd } \\
\text { vedtatt at det kan eta-bleres en } \\
\text { nasjonal database for elektroniske } \\
\text { resepter (Resept-formidleren). Det } \\
\text { følger av } \S 8,4 \text {. ledd at et slikt } \\
\text { helseregister kan regu-leres i egen } \\
\text { forskrift. Denne forskriften regu- } \\
\text { lerer den behandling av helseopp- } \\
\text { lysninger som vil finne sted gjen- } \\
\text { nom Reseptformidleren. }\end{array}$ \\
\hline $\begin{array}{l}\text { Hvor lenge lagres } \\
\text { opplysninger? }\end{array}$ & $\begin{array}{l}\text { Elektronisk e-Recept har giltighets- } \\
\text { tid i ett år, efter att den har kommit } \\
\text { i portalen. Efter ett år gäller den e- } \\
\text { Recept inte längre och raderas. } \\
\text { Apoteken hämtar e-Recepten från } \\
\text { portalen. }\end{array}$ & Oplysningerne slettes efter 2 år. & $\begin{array}{l}\text { Recept har en giltighet på ett år. } \\
\text { Läkare kan förkorta giltighetstid. } \\
\text { Ligger kvar i receptregistret } 15 \\
\text { månader efter sista expedition. } \\
\text { Enligt } 14 \text { § förslaget till apoteks- } \\
\text { datalag ska uppgiften tas bort när } \\
\text { en personuppgift inte längre } \\
\text { behövs för behandling enligt } \\
\text { ända-målen i } 8 \text { §. Avser lokalt } \\
\text { apotek. }\end{array}$ & $\begin{array}{l}\text { Opplysninger lagres i maksimalt } \\
3 \text { år. }\end{array}$ & $\begin{array}{l}\text { Etter at det tjenstlige behovet ikke } \\
\text { lenger er tilstede er det forutsatt at } \\
\text { resepten og opplysningene knyttet } \\
\text { til denne, skal slettes. } \\
\text { Resepter er som hovedregel gyldig } \\
\text { i } 1 \text { år regnet fra den dagen resep- } \\
\text { ter er utstedt. }\end{array}$ \\
\hline
\end{tabular}




\begin{tabular}{|c|c|c|c|c|c|}
\hline & Island & Danmark & Sverige & Finland & Norge \\
\hline $\begin{array}{l}\text { Data- } \\
\text { behandlings- } \\
\text { ansvarlig }\end{array}$ & $\begin{array}{l}\text { Hälsoministeriet har ytterst ansvar } \\
\text { för e-Recept systemet och en } \\
\text { speciell kommitte inom Hälsomini- } \\
\text { steriet, VURL, utför allt arbete om e- } \\
\text { Recept inom ministeriet. Hälsodirek- } \\
\text { toratet är ansvarigt för tillsyn med } \\
\text { systemet. } \\
\text { Allt detta enligt regler från Datain- } \\
\text { spektionen. } \\
\text { (Lag om Datainspektion nr. } \\
\text { 77/2000). }\end{array}$ & $\begin{array}{l}\text { Lægemiddelstyrelsen er dataan- } \\
\text { svarlig }\end{array}$ & $\begin{array}{l}\text { Tillståndshavaren (den som har } \\
\text { fătt tillstånd att bedriva detaljhan- } \\
\text { del med läkemedel) är personupp- } \\
\text { giftsansvarig för den personupp- } \\
\text { gifts-behandling som utförs på ett } \\
\text { öppenvårdsapotek. } \\
\text { Vårdgivaren är enligt } 2 \text { kap. } 6 \text { § } \\
\text { patientdatalagen (2008:355) per- } \\
\text { sonuppgiftsansvarig för sin be-- } \\
\text { handling av personuppgifter, dvs } \\
\text { inom hälso- och sjukvården. } \\
\text { Apotekens Servicebolag AB kom- } \\
\text { mer att fro.m. den } 1 \text { juli vara per- } \\
\text { sonuppgiftsansvarig för receptre- } \\
\text { gistret och läkemedelsförteckning- } \\
\text { en m.m. }\end{array}$ & & $\begin{array}{l}\text { Helsedirektoratet er databehand- } \\
\text { lingsansvarlig for Reseptformidle- } \\
\text { ren. }\end{array}$ \\
\hline $\begin{array}{l}\text { Hvem kan hente } \\
\text { ut opplysninger? }\end{array}$ & $\begin{array}{l}\text { Personal i apoteken. Delvis Islänsk } \\
\text { Försäkring och Hälsodirektoratet } \\
\text { p.g.a. tillsynansvar. }\end{array}$ & $\begin{array}{l}\text { Den læge, der aktuelt har en } \\
\text { patient i behandling, har ad-gang } \\
\text { til de oplysninger, der er registreret } \\
\text { om patienten, når det er nødven- } \\
\text { digt for behand-lingen. } \\
\text { Oplysningerne må alene anven- } \\
\text { delse med henblik på at sikre } \\
\text { kvaliteten, sikkerheden og effekten } \\
\text { af medicin-brugerens lægemiddel- } \\
\text { anvendelse. } \\
\text { Den kommunale hjemme- } \\
\text { sygepleje, herunder på plejehjem, } \\
\text { har adgang til oplysninger, der er } \\
\text { registreret om en patient, når } \\
\text { 1. Patienten har givet mundtligt } \\
\text { eller skriftligt samtykke hertil, } \\
\text { 2. patienten er visiteret til hjemme- } \\
\text { sygeplejen og } \\
\text { 3. adgangen er relevant i forhold til } \\
\text { behandling eller pleje af patienten. } \\
\text { Apotekere og apotekspersonale } \\
\text { har adgang til oplysninger, der er } \\
\text { registreret om ordinationer, når } \\
\text { adgangen er nødvendig for ekspe- } \\
\text { dition af ordinationen. }\end{array}$ & $\begin{array}{l}\text { Behörigheter för åtkomst på } \\
\text { apoteken ska enligt } 12 \S \text { den } \\
\text { föreslagna apoteksdatalagen } \\
\text { begränsas till vad som behövs för } \\
\text { att den som arbetar på ett öp- } \\
\text { penvårdsapotek ska kunna fullgö- } \\
\text { ra sina arbetsuppgifter där. } \\
\text { Patienten själv har direktåtkomst } \\
\text { till uppgifterna i receptregistret, } \\
\text { efter säker inloggning. } \\
\text { Förvaltare på Apotekens Service } \\
\text { AB har tillgång till vissa uppgifter } \\
\text { vid utredning av incidenter. } \\
\text { Farmacevter och förskrivare har } \\
\text { tillgång till Läkemedelsförteck- } \\
\text { ningen (expedierade recept) med } \\
\text { patientens samtycke. } \\
\text { Patienten har tillgång till Läke- } \\
\text { medelsförteckningen. }\end{array}$ & & $\begin{array}{l}\text { Utlevering av opplysninger fra } \\
\text { Reseptformidleren kan skje i } \\
\text { følgende tilfeller: } \\
\text { - Resepter og reseptopplysninger } \\
\text { kan utleveres til apotek innenfor } \\
\text { Reseptformidlerens formål, jf. § 1-2. } \\
\text { - Resepter og reseptopplysninger } \\
\text { om medisinsk forbruksmateriell } \\
\text { eller næringsmidler kan utleveres } \\
\text { til bandasjist innenfor Reseptfor- } \\
\text { midlerens formål, jf. § 1-2. } \\
\text { - Opplysninger i søknad om unntak } \\
\text { fra kravet om markedsføringstilla- } \\
\text { telse jf. § 1-7 nr. } 2 \text { kan utleveres til } \\
\text { Statens legemiddelverk. } \\
\text { - Opplysninger om resepter i } \\
\text { Reseptformidleren som rekviren- } \\
\text { ten selv har rekvirert kan utleveres } \\
\text { til rekvirenten. } \\
\text { - Opplysninger om resepter i } \\
\text { Reseptformidleren kan utleveres til } \\
\text { andre rekvirenter. Slik utlevering } \\
\text { av opplysninger forutsetter pasien- } \\
\text { tens samtykke. }\end{array}$ \\
\hline & & & & & forts.. \\
\hline
\end{tabular}




\begin{tabular}{|c|c|c|c|c|c|}
\hline & Island & Danmark & Sverige & Finland & Norge \\
\hline & & $\begin{array}{l}\text { Derudover har apotekere og } \\
\text { apotekspersonale adgang til de } \\
\text { oplysninger, der er registreret om } \\
\text { en medicinbruger, når denne har } \\
\text { givet mundtligt eller skriftligt sam- } \\
\text { tykke hertil. } \\
\text { Lægemiddelsstyrelsen har som } \\
\text { dataansvarlig angang til oplysnin- } \\
\text { gerne, når det er påkrævet af } \\
\text { driftstekniske grunde eller følger af } \\
\text { Læge-middelstyrelsens forpligtel- } \\
\text { ser m.v.. } \\
\text { Sundhedsstyrelsen har adgang til } \\
\text { oplysningerne, når dette er nød- } \\
\text { vendigt for til-synet med lægers og } \\
\text { tandlægers ordination af afhæn- } \\
\text { gighedsskabende lægemidler og } \\
\text { antipsykotika, og omstændighe-- } \\
\text { derne ikke afdækkes tilstrækkeligt } \\
\text { med de oplysninger, som Sund- } \\
\text { hedsstyrelsen er i besiddelse af. }\end{array}$ & & & $\begin{array}{l}\text { - Opplysninger om hvilke legemid- } \\
\text { ler, medisinsk forbruksmateriell } \\
\text { eller næringsmidler som er utlevert } \\
\text { til pasient på bakgrunn av en } \\
\text { resept kan utleveres fra Resept- } \\
\text { formidleren til den som har rekvi- } \\
\text { rert denne resepten. } \\
\text { - Opplysninger om hvilke legemid- } \\
\text { ler, medisinsk forbruksmateriell } \\
\text { eller næringsmidler som er utlevert } \\
\text { til pasient kan utleveres fra Re- } \\
\text { septformidleren til pasientens } \\
\text { fastlege. Slik utlevering av op- } \\
\text { plysninger forutsetter pasientens } \\
\text { samtykke. }\end{array}$ \\
\hline $\begin{array}{l}\text { Pasientens } \\
\text { innsynsrett }\end{array}$ & $\begin{array}{l}\text { Patienten eller hans ombud har } \\
\text { rätt att fă tillgång till sin journal. } \\
\text { Detta tar lika till information i en } \\
\text { recept. }\end{array}$ & $\begin{array}{l}\text { Patienten har selv adgang til sin } \\
\text { Medicinprofil ved brug af sin } \\
\text { digitale signatur. } \\
\text { Derudover har patienten adgang til } \\
\text { logoplysningerne om, hvem der } \\
\text { har haft adgang til dennes Medi- } \\
\text { cinprofil, til hvilke oplysninger og } \\
\text { hvornår. }\end{array}$ & $\begin{array}{l}\text { Enligt } 16 \S \text { förslaget till apoteks- } \\
\text { datalag ska patienten informeras } \\
\text { om rätten att ta del av uppgifterna } \\
\text { enligt } 26 \text { § personuppgiftslagen } \\
\text { (1998:204). } \\
\text { Patienten har direktåtkomst till } \\
\text { receptregistret (giltiga e-recept) } \\
\text { samt Läkemedelsförteckningen } \\
\text { (expedierade recept) } \\
\text { När det gäller journalinformation } \\
\text { har patienten som huvudregel rätt } \\
\text { att ta del av denna. }\end{array}$ & & $\begin{array}{l}\text { Pasienten har rett til informasjon } \\
\text { om Reseptformidleren og innsyn i } \\
\text { behandling av helseopplysninger } \\
\text { om seg selv i samsvar med helse- } \\
\text { registerloven § } 22 \text { til § } 25 \text {. Infor- } \\
\text { masjonen skal gis i en forstålig } \\
\text { form. }\end{array}$ \\
\hline Samtykke & $\begin{array}{l}\text { Nei. Om patienten säger nej til } \\
\text { erbjudan av recept eller e-Recept } \\
\text { för behandling tolkast det som nej } \\
\text { vid behandling. }\end{array}$ & $\begin{array}{l}\text { Ved samtykke i henhold til be- } \\
\text { stemmelserne forstås enhver } \\
\text { frivillig, specifik og informeret } \\
\text { viljestilkendegivelse, hvorved den } \\
\text { registrerede indvilger i, at oplys- } \\
\text { ninger, der vedrører den pågæl- } \\
\text { dende selv, gøres til genstand for } \\
\text { behandling. Samtykket kan til } \\
\text { enhver tid trækkes tilbage. }\end{array}$ & $\begin{array}{l}\text { Behandling av personuppgifter } \\
\text { som är tillåten enligt förslaget till } \\
\text { apoteksdatalag får enligt } 6 \S \\
\text { utföras även om den enskilde } \\
\text { motsätter sig behandlingen. } \\
\text { När det gäller uppgifter i läkeme- } \\
\text { delsförteckningen, dvs ett register } \\
\text { över köp av förskrivna läkemedel, } \\
\text { är tillgång till uppgifterna endast } \\
\text { ges till förskrivare och farmaceut }\end{array}$ & & $\begin{array}{l}\text { Reseptformidleren behandler } \\
\text { opplysninger uten samtykke fra } \\
\text { pasienten. } \\
\text { Noen behandlinger forutsetter } \\
\text { imidlertid samtykke: } \\
\text { Utlevering av reseptoversikt: } \\
\text { Opplysninger om en pasients } \\
\text { tilgjengelige resepter i registeret } \\
\text { kan utleveres til andre leger enn } \\
\text { den som har rekvirert. Slik utleve- }\end{array}$ \\
\hline
\end{tabular}




\begin{tabular}{|c|c|c|c|c|c|}
\hline & Island & Danmark & Sverige & Finland & Norge \\
\hline & & & $\begin{array}{l}\text { efter uttryckligt samtycke från } \\
\text { patienten. ( 3och } 7 \text { § lagen } \\
\text { (2005:258) om läkemedelsför- } \\
\text { teckning. } \\
\text { Krävs ej samtycke för att skicka } \\
\text { e-recept. Fortsatt lagring av e- } \\
\text { recept för flera uttag i receptre- } \\
\text { gistret kräver samtycke }\end{array}$ & & $\begin{array}{l}\text { ring forutsetter pasientens samtyk- } \\
\text { ke i det enkelte tilfellet. Samtykke } \\
\text { skal innhentes av den lege som } \\
\text { ber om å få utlevert reseptoversik- } \\
\text { ten og dokumenteres i journalen. } \\
\text { Innhenting av samtykke skal be- } \\
\text { kreftes av legen overfor Resept- } \\
\text { formidleren før utlevering kan finne } \\
\text { sted. } \\
\text { Utlevering av reseptopplysninger } \\
\text { til fastlege: } \\
\text { Opplysninger om hvilke legemid- } \\
\text { ler, medisinsk forbruksmateriell } \\
\text { eller næringsmidler som er utlevert } \\
\text { til pasient kan utleveres fra Re- } \\
\text { septformidleren til pasientens } \\
\text { fastlege. Slik utlevering av opplys- } \\
\text { ninger forutsetter pasientens } \\
\text { samtykke. Samtykke skal innhen- } \\
\text { tes av fastlegen og dokumenteres i } \\
\text { journalen. Innhenting av samtykke } \\
\text { skal bekreftes av fastlegen overfor } \\
\text { Reseptformidleren før utlevering } \\
\text { kan finne sted. Samtykket gjelder } \\
\text { inntil pasienten trekker det tilbake, } \\
\text { bytter fastlege eller trer ut av } \\
\text { fastlegeordningen. } \\
\text { Pasienter som har gitt samtykke } \\
\text { etter første ledd, kan likevel ved } \\
\text { utlevering av legemidler, medi- } \\
\text { sinsk forbruksmateriell eller nær- } \\
\text { ingsmidler reservere seg mot at } \\
\text { det gis tilbakemelding til fastlege i } \\
\text { det enkelte tilfellet. }\end{array}$ \\
\hline $\begin{array}{l}\text { Krav til infor- } \\
\text { masjons-sikkerhet }\end{array}$ & $\begin{array}{l}\text { Gäller almänna krav om informa- } \\
\text { tinsäkerhet i handling med e- } \\
\text { Recepter och bestäm-mes av lagar } \\
\text { och förordingar. }\end{array}$ & Der kræves digitalsignatur. & $\begin{array}{l}\text { I den utsträckning lagen } \\
\text { (2005:258) om läke- } \\
\text { medelsförteckning eller lagen } \\
\text { (1996:1156) om receptregister } \\
\text { inte innehåller bestämmelser som } \\
\text { reglerar säkerheten vid behand- } \\
\text { ling av personuppgifter, är be- } \\
\text { stämmelserna i personuppgiftsla- } \\
\text { gen (1998:204) tillämpliga. Detta }\end{array}$ & & $\begin{array}{l}\text { Helsedirektoratet har som databe- } \\
\text { handlingsansvarlig ansvar for å } \\
\text { sørge for tilfredsstillende informa- } \\
\text { sjonssikkerhet når helseopplys- } \\
\text { ninger behandles. Informasjons- } \\
\text { sikkerheten skal være tilfredsstil- } \\
\text { lende med hensyn til }\end{array}$ \\
\hline
\end{tabular}




\begin{tabular}{|c|c|c|c|c|c|}
\hline & Island & Danmark & Sverige & Finland & Norge \\
\hline & & & $\begin{array}{l}\text { innebär bl.a. att Apotekens Servi- } \\
\text { ce AB, som personuppgift- } \\
\text { sansvarigt enligt } 31 \S \text { §, ska vidta } \\
\text { lämpliga tek-niska och organisa- } \\
\text { toriska åtgärder för att skydda } \\
\text { personuppgifterna och därmed } \\
\text { åstadkomma en säkerhetsnivå } \\
\text { som är lämplig med beaktande } \\
\text { av hur känsliga upp-gifterna är, } \\
\text { vilka tekniska möjligheter som } \\
\text { finns, de särskilda risker som } \\
\text { finns med behandlingen av upp- } \\
\text { gifterna samt vad det skulle kosta } \\
\text { att genom-föra åtgärderna. (prop. } \\
\text { 2008/09:145 s. 324) I förslaget till } \\
\text { apoteks-datalagn finns också } \\
\text { bestämmelser om behörighetstill- } \\
\text { delning och åtkomstkontroll. } \\
\text { Samtliga e-recept kräver signering } \\
\text { och kryptering på servernivå. Ej } \\
\text { krav på individuell elektronisk } \\
\text { signatur för förskrivaren fn. }\end{array}$ & & $\begin{array}{l}\text { konfidensialitet, integritet, til- } \\
\text { gjengelighet og kvalitet. } \\
\text { Tilfredsstillende informasjonssik- } \\
\text { kerhet skal oppnås ved hjelp at } \\
\text { planlagte og systemtiske tiltak. } \\
\text { Dette innbærer at anerkjente } \\
\text { teknikker og standarder for kvali- } \\
\text { tetssikring, internkontroll og infor- } \\
\text { masjonssikkerhet skal legger til } \\
\text { grunn. Tiltakene som etableres } \\
\text { kan både være organisatoriske og } \\
\text { tekniske. Tiltakene og selve } \\
\text { informasjonssystemet skal kunne } \\
\text { dokumenteres. }\end{array}$ \\
\hline $\begin{array}{l}\text { Organisering av } \\
\text { e-resept-tjenesten }\end{array}$ & $\begin{array}{l}\text { I Hälsoministeriet finns en kommit- } \\
\text { te (VURL) som är ansvarig för } \\
\text { driften av e-Recept systemet. } \\
\text { Tjänsten är outsourced till ett } \\
\text { företag som har hand om både } \\
\text { drift av den centrala receptportalen } \\
\text { samt kommunikationsleden under } \\
\text { ett kontrakt och kontroll med } \\
\text { Hälsoministeriet (VURL). }\end{array}$ & $\begin{array}{l}\text { Lægemiddelstyrelsen er ansvarlig } \\
\text { for drift af tjenesten }\end{array}$ & $\begin{array}{l}\text { Apotekens Servicebolag } A B \text { är } \\
\text { ansvarig. Driften är outsorcad till } \\
\text { underleverantör. }\end{array}$ & & $\begin{array}{l}\text { De ulike aktører i reseptbehand- } \\
\text { lingen vil ha det samme ansvar og } \\
\text { oppgaver som i dag, og også } \\
\text { ansvar for å tilpasse sine datasys- } \\
\text { temer. Helsedirektoratet gir til- } \\
\text { skudd til utviklingen. } \\
\text { Helsedirektoratet har ansvar for } \\
\text { Reseptformidleren, og å forvalte } \\
\text { de standarder som benyttes for å } \\
\text { kommunisere med Reseptformid- } \\
\text { leren og får dermed en sentral } \\
\text { rolle. } \\
\text { Helsedirektorat har ansvaret for } \\
\text { eReseptprogrammet. Forvaltning- } \\
\text { en av hele eReseptløsningen etter } \\
\text { programperioden er ikke besluttet. }\end{array}$ \\
\hline
\end{tabular}




\begin{tabular}{|c|c|c|c|c|c|}
\hline & Island & Danmark & Sverige & Finland & Norge \\
\hline Tilsyn & $\begin{array}{l}\text { Hälsodirektoratet har tillsyn på } \\
\text { regular basis och har därför ac- } \\
\text { cess till portalen. }\end{array}$ & $\begin{array}{l}\text { Lægemiddelstyrelsen som dataan- } \\
\text { svarlig, og foretager stikprøveun- } \\
\text { dersøgelser på udvalgte emner. } \\
\text { Endvidere foretages undersøgelse } \\
\text { af henvendelser fra folk, der } \\
\text { mener, at der er fejl i registrerin- } \\
\text { gerne, eller opdrager uberettiget } \\
\text { adgang til oplysninger. }\end{array}$ & $\begin{array}{l}\text { Datainspektionen är tillsynsmyn- } \\
\text { dighet för behandling av person- } \\
\text { uppgifter. } \\
\text { Socialstyrelsen har tillsyn över } \\
\text { hälso- och sjukvården och dess } \\
\text { personl, dvs även över den hälso- } \\
\text { och sjukvårdspersonal som läm- } \\
\text { nar ut läkemedel på apotek. } \\
\text { Läkemedelsverket är tillsynsmyn- } \\
\text { dighet för apotek och efterlevna- } \\
\text { den av den nya lagen om handel } \\
\text { med läkemedel. } \\
\text { Tandvårds- och läkemedelsför- } \\
\text { månsverket föreslås ha tillsyn } \\
\text { över efter-levanden av lagen om } \\
\text { läkemedelsförmåner m.m. }\end{array}$ & & $\begin{array}{l}\text { Både Datatilsynet og Statens } \\
\text { helsetilsyn/Helsetilsynet i fylket har } \\
\text { ansvar når det gjelder å kontrollere } \\
\text { at helseopplysninger behandlers i } \\
\text { samsvar med helseregisterloven, } \\
\text { jf. helseregisterloven § } 31 \text {. Datatil- } \\
\text { synet fører tilsyn i forhold til per- } \\
\text { sonvernfaglige spørsmål, mens } \\
\text { Helsetilsynet har ansvaret i forhold } \\
\text { til helsefaglige spørsmål. }\end{array}$ \\
\hline Klageadgang & $\begin{array}{l}\text { Alla partier som handlar om e- } \\
\text { Recept (patient, läkare och perso- } \\
\text { nal i apotek) kan klaga til Hälsodi- } \\
\text { rektoratet som är ansvarig för } \\
\text { driften av e-Recept systemet. }\end{array}$ & $\begin{array}{l}\text { Alle, der opdager fejl i de registre- } \\
\text { rede oplysninger, eller som mener, } \\
\text { at nogen har haft uberettiget } \\
\text { adgangsret til systemets oplysnin- } \\
\text { ger, kan man klage til Læge- } \\
\text { middelstyrelsen. }\end{array}$ & $\begin{array}{l}\text { En registrerad kan anmäla till } \\
\text { Data-inspektionen om han eller } \\
\text { hon är missnöjd med behandling- } \\
\text { en av personuppgifter. } \\
\text { En patient som är missnöjd med } \\
\text { hälso- och sjukvård kan antingen } \\
\text { anmäla till Hälso- och sjukvår- } \\
\text { dens ansvars-nämnd (om patien- } \\
\text { ten anser att en yrkesutövare } \\
\text { gjort något fel) eller till Socialsty- } \\
\text { relsen. } \\
\text { Bestämmelserna i personupp- } \\
\text { giftslagen (1998:204) om rättelse } \\
\text { och skadestånd gäller vid be- } \\
\text { handling av person-uppgifter } \\
\text { enligt den föreslagna apoteks- } \\
\text { datalagen. }\end{array}$ & & $\begin{array}{l}\text { Dersom Datatilsynet avdekker at } \\
\text { det behandles helseopplysninger i } \\
\text { strid med loven eller tilhørende } \\
\text { forskrifter har Datatilsynet adgang } \\
\text { til å gi pålegg om endring eller } \\
\text { opphør av den ulovlige behand- } \\
\text { lingen. Dersom datatilsynet gir } \\
\text { pålegg kan det samtidig fastsette } \\
\text { en tvangsmulkt. Den databehand- } \\
\text { lingsansvarlige kan påklage } \\
\text { avgjørelsen til Personvernnemnda. }\end{array}$ \\
\hline Betaling & $\begin{array}{l}\text { Samma system liksom med al- } \\
\text { männa recept. } \\
\text { Utenlandske resepter: } \\
\text { Som regel betalar patienten full } \\
\text { pris för läkemedelen och kan få } \\
\text { àterbetalt från sitt eget lands } \\
\text { försäkringskassa. }\end{array}$ & $\begin{array}{l}\text { Betaling for den elektroniske } \\
\text { ydelse sker af Lægemiddel- } \\
\text { styrelsen over netto-bevilingen, det } \\
\text { vil sige som en del af det statsfi- } \\
\text { nansierede tilskud til drift af styrel- } \\
\text { sen. }\end{array}$ & $\begin{array}{l}\text { Lagen (2002:16) om läkemedels- } \\
\text { förmåner m.m. innehåller be- } \\
\text { stämmelser om bl.a. läkemedels- } \\
\text { förmåner och prisreglering av } \\
\text { varor som ingår i förmånen. Det } \\
\text { är endast läkemedel som är } \\
\text { avsedda att tillföras människor }\end{array}$ & & $\begin{array}{l}\text { Folketrygden yter stønad til dek- } \\
\text { ning av viktige legemidler og } \\
\text { medisinsk forbruksmateriell og } \\
\text { næringsmidler, jf. folketrygdloven § } \\
5-14 \text { og tilhørende forskrift } 28 \text {. juni } \\
2007 \text { nr. } 814 \text { om stønad til dekning } \\
\text { av utgifter til viktige legemidler mv. }\end{array}$ \\
\hline
\end{tabular}




\begin{tabular}{|c|c|c|c|c|c|}
\hline & Island & Danmark & Sverige & Finland & Norge \\
\hline & & & $\begin{array}{l}\text { som omfattas av läke- } \\
\text { medelsförmånerna. Med läkeme- } \\
\text { delsförmåner avses ett skydd mot } \\
\text { höga kostnader vid inköp av } \\
\text { förmånsberättigade varor. } \\
\text { Rätt till förmåner enligt denna lag } \\
\text { har den som är bosatt i Sverige } \\
\text { och den som, utan att vara bosatt } \\
\text { här, har rätt till vård-förmåner i } \\
\text { Sverige vid sjukdom eller mo- } \\
\text { derskap enligt vad som följer av } \\
\text { rådets förordning (EEG) nr } \\
\text { 1408/71 av den } 14 \text { juni 1971 om } \\
\text { tillämpningen av systemen för } \\
\text { social trygghet när anställlda, } \\
\text { egenföretagare eller deras famil- } \\
\text { jemed-lemmar flyttar inom ge- } \\
\text { men-skapen. Rätt till högkost- } \\
\text { nadsskydd, med undantag för } \\
\text { förbruk-ningsartiklar som behövs } \\
\text { vid stomi, har även den som utan } \\
\text { att vara bosatt i Sverige har an- } \\
\text { ställning här. (prop. 2008/09:145 } \\
\text { s. } 71 \text { ) Enligt } 5 \text { § lagen (2002:160) } \\
\text { om läke-medelsförmåner m.m. } \\
\text { uppgår det maximala beloppet } \\
\text { som en förmånsberättigad person } \\
\text { ska behöva betala under en } \\
\text { period om tolv månader till } 1 \text { 800 } \\
\text { kronor (högkostnadsskyddet). }\end{array}$ & & $\begin{array}{l}\text { For å få refusjon for resepter må } \\
\text { resepten være utformet i henhold } \\
\text { til det norske regelverket for } \\
\text { refusjon (blåresept-forskriften). } \\
\text { Fordi resepter fra andre nordiske } \\
\text { land normalt ikke vil være utformet } \\
\text { slik, vil pasienten måtte betale full } \\
\text { pris på apoteket. }\end{array}$ \\
\hline $\begin{array}{l}\text { System- } \\
\text { beskrivelse }\end{array}$ & $\begin{array}{l}\text { e-Recepter skickas från läkare in } \\
\text { till receptportalen via hälsonättet } \\
\text { Hekla. Receptportalen vidaresän- } \\
\text { der e-Receptet till det apotek dit } \\
\text { receptet skall skickas om läkaren } \\
\text { har önskat det. Om han inte har } \\
\text { gjort det stannar receptet i portalen } \\
\text { tills patienten kommer till apoteket } \\
\text { och apoteks-personalen hämtar } \\
\text { receptet från portalen. }\end{array}$ & $\begin{array}{l}\text { Systemet er et trans- } \\
\text { aktionssystem, som udstiller data } \\
\text { på en WEB-løsning. } \\
\text { Transaktionsdata - recepter og } \\
\text { kvitteringer - udveksles ved brug af } \\
\text { webservices, hovedsagligt af } \\
\text { praktiserende læger og apoteker. } \\
\text { Borgere, læger og apoteker kan se } \\
\text { status på borgerens recepter } \\
\text { gennem en web-side, ligesom } \\
\text { lægen kan oprette og apoteket kan } \\
\text { ekspedere en recept. }\end{array}$ & $\begin{array}{l}\text { Systemet är transaktionssystem } \\
\text { Ett nationellt e-receptformat är } \\
\text { fasttälltt i XML. Teknik för överfö- } \\
\text { ring till Receptregistret är X.400, } \\
\text { smtp samt webservices. } \\
\text { Förskrivare skickar receptet till en } \\
\text { nationell receptbrevlåda som } \\
\text { även benämns receptregistret. } \\
\text { Receptet ligger i receptregistret } \\
\text { tills kunden avropar en expedi- } \\
\text { tion. }\end{array}$ & $\begin{array}{l}\text { Sentral eReseptdatabase } \\
\text { Helseinstitusjoner og apotek } \\
\text { kobler seg til databasen. }\end{array}$ & (Se figur under tabellen). \\
\hline
\end{tabular}




\begin{tabular}{|c|c|c|c|c|c|}
\hline & Island & Danmark & Sverige & Finland & Norge \\
\hline & $\begin{array}{l}\text { Efter det att receptet har bearbe- } \\
\text { tats skickas inform-ation från } \\
\text { apoteket till portalen att receptet } \\
\text { har använts. Portalen markerar } \\
\text { receptet som avklarat och vid ett } \\
\text { senare tilfelle raderas alla avklara- } \\
\text { de recept. } \\
\text { Ett e-Recept har giltighets-tiden ett } \\
\text { år och om patienten inte har } \\
\text { hämtat sin medicin vid det tilfellet, } \\
\text { så raderas receptet vid nästa } \\
\text { tilfelle då Hälsodirektoratet gör sitt } \\
\text { kontroll och radering. }\end{array}$ & $\begin{array}{l}\text { Den elektroniske proces for en } \\
\text { recept kan beskrives med følgende } \\
\text { trin: } \\
\text { En recept (en eller flere ordinatio- } \\
\text { ner på lægemiddel) sendes elek- } \\
\text { tronisk fra den praktiserende læge. } \\
\text { Recepten behandles på en central } \\
\text { receptserver, som fungerer som } \\
\text { recepthotel og er synlig for borger, } \\
\text { læger og apoteker. } \\
\text { Borgeren går til et apotek for at få } \\
\text { ekspederet recepten. } \\
\text { Efter at have fået sin medicin } \\
\text { ligger receptdata fortsat på syste- } \\
\text { met i } 2 \text { år fra registreringen. } \\
\text { Systemet er bygget i Java kode, } \\
\text { database er Oracle og applikation } \\
\text { afvikles gennem Trifork applikati- } \\
\text { onsplatform. } \\
\text { Se også nedenstående figurer } 1 \\
\text { og } 2\end{array}$ & $\begin{array}{l}\text { Recepten kan hämtas på alla } \\
\text { apotek i normalfallet. Förskriva- } \\
\text { ren har möjlighet att adressera } \\
\text { receptet till ett enskilt apotek som } \\
\text { då kan förbereda innan ikunden } \\
\text { kommer till apoteket } \\
\text { kunden hämtar sin medicin på } \\
\text { valfritt apotek } \\
\text { receptregistret uppdateras med } \\
\text { expeditionsdata } \\
\text { Patienter och farmacevter har } \\
\text { tillgång till receptregistret. }\end{array}$ & & \\
\hline $\begin{array}{l}\text { Tilgang til } \\
\text { systemet }\end{array}$ & $\begin{array}{l}\text { Direkt tillgång till portalen har } \\
\text { endast den personnel som har } \\
\text { hand om teknisk drift och under- } \\
\text { håll, samt Hälso-direktoratets } \\
\text { personnel. } \\
\text { Apotekens system har till-gång till } \\
\text { portalen på det viset att ett per- } \\
\text { sonnumer skickas till portalen och } \\
\text { tillbaka kommer översikt över de } \\
\text { recept sem finns för denna person. } \\
\text { Apoteken behöver att uppfylla } \\
\text { vissa krav frán VURL (Hälosminis- } \\
\text { teriet) om datautrusning, datasy- } \\
\text { stem och informationsäkerhet till } \\
\text { att få permission att uföra sin e- } \\
\text { recept tjänst. }\end{array}$ & Web services og web GUI & $\begin{array}{l}\text { Idag är elektronisk förmedling av } \\
\text { recept tillåtet efter avtal mellan } \\
\text { sjukvårdshuvudman- } \\
\text { nen/receptutfärdaren och det } \\
\text { aptoekt som lämnar ut läkemedel } \\
\text { (36 § Läkemedelsverkets före- } \\
\text { skrifter (LVFS 1997:10) om för- } \\
\text { ordnande och utlämnande av } \\
\text { läkemedel m.m. (receptföreskrif- } \\
\text { ter). } \\
\text { Sedan ansvarar Apoteket AB för } \\
\text { säkra behörighets och åtkomst- } \\
\text { regler enligt personuppgiftslagen. } \\
\text { Fr.o.m. den } 1 \text { juli gäller apoteks- } \\
\text { datalagen och de behörighets- } \\
\text { och åtkomstregler som gäller } \\
\text { enligt denna lag, se ovan. } \\
\text { För personuppgifter inom hälso- } \\
\text { och sjukvården gäller behörig- } \\
\text { hets- och åtkomstregler enligt }\end{array}$ & $\begin{array}{l}\text { Tilgang for helsepersonell, insti- } \\
\text { tusjoner og apotek } \\
\text { Pasienter skal få tilgang til egne } \\
\text { resepter. }\end{array}$ & $\begin{array}{l}\text { Ut over det som er nødvendig av } \\
\text { teknisk tilgang for et mest mulig } \\
\text { begrenset antall av driftspersonale } \\
\text { hos databehandleren, har ingen } \\
\text { tilgang (i Helseregisterlovens } \\
\text { forstand) til Reseptformidleren. } \\
\text { Melding til og utlevering av opp- } \\
\text { lysninger fra Reseptformidleren } \\
\text { skjer på bakgrunn av følgende } \\
\text { autentisering og autorisering. } \\
\text { All autentisering i eResept- } \\
\text { løsningen baserer seg på PKI. } \\
\text { Virksomheten autentiseres ved at } \\
\text { alle meldinger signeres med } \\
\text { avsenders virksomhetssertifikat. } \\
\text { I tillegg signeres innholdet i alle } \\
\text { meldinger fra rekvirenten med } \\
\text { personlig sertifikat på høyeste } \\
\text { nivå. Dette gir alle aktører som }\end{array}$ \\
\hline
\end{tabular}




\begin{tabular}{|c|c|c|c|c|c|}
\hline & Island & Danmark & Sverige & Finland & Norge \\
\hline & & & $\begin{array}{l}\text { patientdatalagen och Socialsty- } \\
\text { relsens föreskrifter (SOSFS } \\
\text { 2008:14) om informationshanter- } \\
\text { ing och journalföring. } \\
\text { http://www.socialstyrelsen.se/Pub } \\
\text { licerat/2008/10109/2008-10- } \\
\text { 14.htm } \\
\text { Apotek och patient har tillgång till } \\
\text { receptregistret. }\end{array}$ & & $\begin{array}{l}\text { behandler resepten mulighet til å } \\
\text { konstatere dens ekthet. } \\
\text { Autorisering av utleverer- } \\
\text { virksomhetene (apotek og banda- } \\
\text { sjister) skjer ved at organisasjons- } \\
\text { nummer fra sertifikat sjekkes mot } \\
\text { myndighetenes konsesjonsregistre } \\
\text { for apotek og tilsvarende register } \\
\text { for bandasjister. Autentisering og } \\
\text { autorisering av den enkelte bruker } \\
\text { hos utlevererne er virksomhetens } \\
\text { ansvar og skjer i deres systemer. }\end{array}$ \\
\hline Kryptering & $\begin{array}{l}\text { e-Recept krypteras i kommunika- } \\
\text { tionen mellan läkare och portal och } \\
\text { mellan portal och apotek. } \\
\text { Personnummer på recept krypte- } \\
\text { ras i receptportalen. }\end{array}$ & $\begin{array}{l}\text { Der kræves kryptering med digital } \\
\text { signatur (http://www.digitalsigna- } \\
\text { tur.dk) ved brug med web GUI. } \\
\text { Webservices anvendes over VPN. }\end{array}$ & $\begin{array}{l}\text { Samtliga e-recept kräver signe- } \\
\text { ring och kryptering på servernivå. } \\
\text { Ej krav individuell elektronisk } \\
\text { signatur för förskrivaren fn. } \\
\text { Enligt } 31 \text { § person-uppgiftslagen } \\
\text { ska den personuppgiftsansvarige } \\
\text { vidta lämpliga tekniska och orga- } \\
\text { nisatoriska åtgärder för att skyd- } \\
\text { da personuppgifter. Det innebär } \\
\text { enligt förslaget till apoteksdatalag } \\
\text { att personuppgifterna skyddas, } \\
\text { t.ex. genom kryptering för att } \\
\text { förhindra att person-uppgifterna } \\
\text { förstörs, ändras eller förvanskas } \\
\text { vid överföring via nät och för att } \\
\text { skydda mot obehörig åtkomst. } \\
\text { (prop. 2008/09:145 s. 324). Lag- } \\
\text { förslaget innehåller också bes- } \\
\text { tämmeler om behörighetstilldel- } \\
\text { ning pch åtkomstkontroll. }\end{array}$ & $\begin{array}{l}\text { Sterk autentisering og digitale } \\
\text { signaturer for både lege og } \\
\text { apotek. } \\
\text { Bruk av smart-card og SSL- } \\
\text { sikkerhet. }\end{array}$ & $\begin{array}{l}\text { I eResept skal konfidensialitet } \\
\text { under overførsel mellom aktørene } \\
\text { sikres ved bruk av PKI-basert } \\
\text { kryptering basert på mottagers } \\
\text { virksomhetssertifikat. } \\
\text { Kryptering skal minst benytte } \\
\text { «3DES». }\end{array}$ \\
\hline Standarder & $\begin{array}{l}\text { Själva e-Receptet är ett subset av } \\
\text { ENV } 13607 \text { i XML format från mai } \\
2000 .\end{array}$ & $\begin{array}{l}\text { MEDcom standarder, Den gode } \\
\text { webservice mm. } \\
\text { se http://medcom.dk/ } \\
\text { default.asp?id=109823 }\end{array}$ & Subset till ENV $13607 \mathrm{i}$ XML & & \\
\hline
\end{tabular}




\begin{tabular}{|c|c|c|c|c|c|}
\hline & Island & Danmark & Sverige & Finland & Norge \\
\hline $\begin{array}{l}\text { Annen relevant } \\
\text { informasjon }\end{array}$ & $\begin{array}{l}\text { Det er viktigt att påpeka att i } \\
\text { systemet förekommer ingen } \\
\text { lagring a recept eller receptdata } \\
\text { utom för det ändamål att flytta } \\
\text { receptet från läkare till apotek. } \\
\text { Olika lagar gäller inom nordiska } \\
\text { länderna om e-Recepter och den } \\
\text { här kartläggningen kan peka på } \\
\text { dessa olikheter i lagarna. Olika } \\
\text { lösningar gäller ang. kommunika- } \\
\text { tion med recepter inom nordiska } \\
\text { länderna. Till att lösa detta kom- } \\
\text { munika-tionsproblem kan en } \\
\text { lösning vara att etablera en } \\
\text { gemensam portal för nordiska } \\
\text { länderna. Det är sannolikt att olika } \\
\text { standarer används i komminaka- } \\
\text { tion med e-Recepter inom de } \\
\text { nordiska länderna. Vi tror att detta } \\
\text { kan koordineras på enkelt sätt. }\end{array}$ & & & & \\
\hline
\end{tabular}


Systembeskrivelse - eResept, Danmark

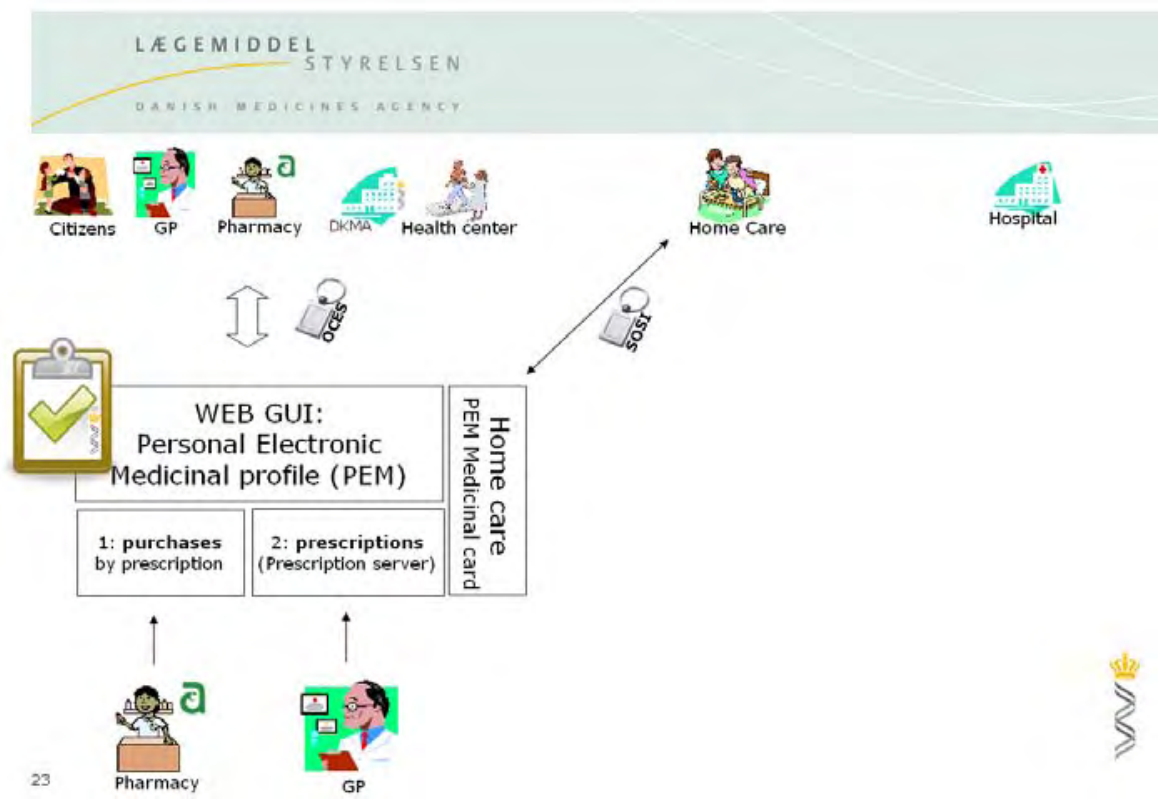

Figur 1: Anvendelse av elektronisk recept, adgang fra borger, lcege og apotek, samt hjemmesygepleie.

\section{Parallel receptfremførsel overblik}

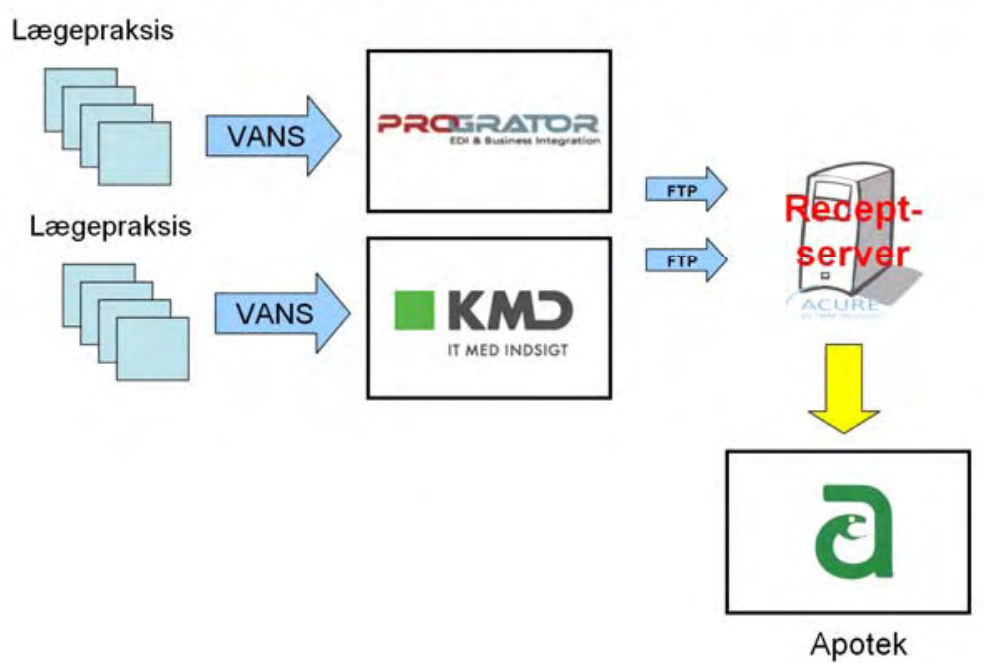

Figur 2: Illustrerer elektronisk foresendelse av recepter fra lage til apotek. Efter godkennelse og behandling på receptserver returnerer serveren en kvittering til afsender. 


\subsection{Kartleggingen - oppsummert}

Kartleggingen, slik den blir presentert over, er i seg selv et sammendrag og en oppsummering av landenes strategier, policy, løsninger og planer. Vi vil her presentere noen av de viktigste punktene og de funnene vi kan hente ut fra kartleggingen.

\subsubsection{Status}

Vi var kjent med at det var til dels store ulikheter mellom landene i forhold til hvor langt de var kommet i innføring av e-resepter. Kartleggingen viser dette tydelig. Sverige har kommet langt, har e-resept utbredt over hele landet og har systemet i rutinemessig bruk. På den andre enden av skalaen finner vi Norge som er i en tidlig fase og i skrivende stund er i gang med de første pilotene.

Dersom vi ser nærmere på landenes planer, vil bildet se helt annerledes ut om 2 - 5 år. I løpet av de nærmeste årene tar alle de nordiske land sikte på å ha e-resept i bruk i stor skala og ser for seg at så godt som alle resepter håndteres elektronisk.

\subsubsection{Målsettinger}

Kartleggingen viser tydelig at landenes mål for innføring av elektroniske resepter er i stor grad sammenfallende. Stikkord er:

\section{- Effektivitet}

- Det å gjøre håndteringen av resepter elektronisk skal gjøre prosessen raskere, billigere og med mindre risiko for feil. Informasjon skal gå raskt og enkelt mellom de aktørene som skal ha informasjonen.

- Sikrere resepthåndtering

- $\quad$ Minimere mulighetene for feil

- Bedre kvalitet

- Bedre kontroll

- $\quad$ Alle landene fremhever betydningen av å få bedre kontroll med forskrivning av reseptbelagte medikamenter og ikke minst bedre økonomikontroll.

I alle de nordiske landene pekes det også på at pasientene har rett til fritt å velge hvilket apotek hun/han ønsker å hente ut medisiner ved. Den elektroniske reseptløsningen skal være med på å sikre denne rettigheten for pasientene. 
Island påpeker også at man gjennom etablering av e-resepter også håper å kunne forbedre pasientenes «compliance», altså sikre at pasientene faktisk tar de medikamentene som blir forskrevet og at de tas i rett doser, til riktig tid osv. Såkalt «non-compliance» er et stort problem over hele verden. Dersom elektroniske resepter kan bidra til å bedre denne situasjonen, vil dette utvilsomt ha stor verdi, både økonomisk og medisinsk.

\subsubsection{Juridisk - generelt}

De nordiske landene er velferdsstater og rettsstater med et omfattende helsevesen og tilhørende omfattende regelverk knyttet til helse og også formidling av helseinformasjon. I alle landene har man derfor lagt ned et stort arbeid i å ha på plass et regelverk som sørger for at elektronisk resepthåndtering kan skje innenfor sikre rammer og som sørger for at vesentlige personlige-, profesjonelle og samfunssmessige interesser blir ivaretatt.

Vi ser at det i alle landene har vedtatt egne lover om elektronisk reseptbehandling. Resepthåndtering handler om håndtering av helseinformasjon og ulike former for elektronisk behandling av slik informasjon. I tråd med dette har også de fleste landene gjort endringer i lovgivningen om behandling av personopplysninger og om behandling av helseinformasjon.

\subsubsection{Pasientens samtykke}

Ingen av de nordiske landene har basert sine elektroniske reseptsystemer på pasientenes samtykke. Dette er i tråd med etablert praksis og også EUs ordninger slik de blant annet kommer til uttrykk i personverndirektivet. Lov er et selvstendig grunnlag for behandling av informasjon, og behandlingen kan skje uavhengig av pasientens samtykke. Slik er det for eksempel for etablering og bruk av pasientjournaler.

\subsubsection{Informasjonsbehandling}

Elektronisk håndtering av resepter er en form for elektronisk behandling av sensitiv informasjon og er som sådan omfattet av landenes regelverk knyttet til behandling av personopplysninger, helselovgivningen og annen lovgivning knyttet mer spesifikt til behandling av medikamenter.

\subsubsection{Databehandlingsansvar}

Plasseringen av databehandlingsansvaret varierer noe basert på hvordan selve e-reseptløsningen er organisert. På Island har Helseministeriet ansvaret, i Norge er ansvaret lagt til Helsedirektoratet mens Sverige, fra 1. juli 2009, kommer til å plassere databehandlingsansvaret hos Apotekenes servicebolag AB, ihht til ny lovgivning. 
I Sveriges svar på kartleggingen pekes det for øvrig på det faktum at det er flere aktører med i hele den prosessen som utgjør elektronisk behandling av resepter og at det er flere som har databehandlingsansvar. Legen har det for sine registre, sykehusene for sine og apotekene for sine.

\subsubsection{Opplysninger som innhentes}

Det er, ikke overraskende, stor likhet mellom landene når det gjelder hva slags informasjon som behandles i de nasjonale systemene:

- Opplysninger om forskrivende lege (eller annet personell som har adgang til å skrive ut resepter)

- Helsepersonellets nummer i det nasjonale helsepersonellregisteret.

- Opplysninger og identifisering av pasienten

- Ulike ordninger for identifisering av pasientene

- Opplysninger om legemidlet

- Opplysninger om bruk av legemidlet

- Opplysninger om utstedende apotek

- Herunder opplysninger om eventuelle endringer som blir gjort av apoteket/apotekeren.

\subsubsection{Hvor lenge opplysningene lagres}

Opplysningene lagres i det elektroniske reseptsystemet så lenge det er bruk for dem. Det vil, som regel, si at opplysninger slettes når de forskrevne medikamentene er hentet ut av pasienten. De fleste landene har en lengste «levetid» for resepten på ett år. Etter utløpet av ettårsfristen må det skrives ut ny resept.

\subsubsection{Pasientens innsynsrett}

Pasientenes rett til innsyn og informasjon om hvordan informasjonen behandles følger alminnelig helselovgivning og lovgivning knyttet til behandling av personopplysninger. Alle landene anerkjenner pasientenes rett til å få informasjon også om hvordan opplysninger om dem behandles. Dette må inkludere informasjon knyttet til resepter og elektroniske resepter.

\subsubsection{Organisering av tjenesten}

Kartleggingen viser at resepttjenestene er organisert ulikt i de ulike landene. Man finner naturligvis de vanlige aktørene, legen, sykehuset og apoteket (m.fl.) men i tillegg finner man den organisatoriske forankringen av den elektroniske reseptløsningen.

I Sverige er man i ferd med å etablere en ny ordning der den elektroniske resepten er forankret i Apotekenes Servicebolag AB mens resept- 
håndteringen kan gjøres av alle apoteker som får bevilgning. ${ }^{16}$ I Norge forankres selve Reseptformidleren i Helsedirektoratet og direktoratet gir tilskudd til at de andre aktørene i «verdikjeden» skal få mulighet til å behandle resepter elektronisk (og knytte seg til Reseptformidleren). Island har etablert en egen komité innenfor Helseministeriet som har ansvar for driften av e-reseptsystemet.

I forhold til det å etablere en felles nordisk e-reseptløsning har det antakelig ikke særlig stor betydning hvordan de nasjonale tjenestene er organisert. I alle de nordiske landene er det en stor grad av statlig/offentlig styring med resepthåndteringen - også den elektroniske. Det viktige i vår sammenheng er å vite noe om den nasjonale organiseringen og ikke minst å kunne identifisere de aktørene som vil være relevante å involvere i en videre prosess for å få til en pan-nordisk løsning og/eller tjeneste.

\subsubsection{Teknisk løsning}

Nordisk eHelseforum har ikke hatt et sterkt fokus på den/de tekniske løsningen(e) i dette arbeidet. Vi anerkjenner likevel at det er helt nødvendig både å se nærmere på de ulike løsningene man har valgt i de nordiske landene og naturligvis også på hvilke muligheter som finnes for å få til en nordisk løsning.

Kort oppsummert ser bildet slik ut i forhold til de nasjonale løsningene:

Island Receptportal tilknyttet det nasjonale helsenettet HEKLA

Danmark Sentral database. Nasjonal reseptserver. Integrert gjennom et sikret datanett og den nasjonale helseportalen.

Sverige Nationell e-recept-databas.

Kommunikasjon gjennom et sikkert nettverk (Sjunet)

Finland Sentral e-reseptdatabase

Norge Sentral database («Reseptformidleren»)

Nasjonalt helsenett (www.nhn.no)

Vi kommer noe tilbake til spørsmålet om valg av teknisk løsning nedenfor i våre konklusjoner og anbefalinger.

\footnotetext{
${ }^{16} \mathrm{http}: / /$ www.regeringen.se/content/1/c6/12/09/69/3c2ee564.pdf
} 



\section{Konklusjoner og anbefalinger}

\subsection{Innledning}

Vårt oppdrag har vært å analysere de enkelte lands e-reseptordninger og å vurdere disse med tanke på muligheten for å utvide disse ordningene slik at også elektroniske resepter kan benyttes over landegrensene i Norden. Som rapporten viser er det en del forhold som må utredes nærmere og en del avgjørelser som må tas før man kan ha på plass e-reseptløsninger mellom de nordiske landene.

Som vi har nevnt over er det etter vår oppfatning helt nødvendig at de nordiske helsemyndighetene starter et arbeid med sikte på å få til en felles nordisk løsning. Gjennom avtaleverk og lovverk har alle landene påtatt seg forpliktelser overfor hverandre (og også overfor land i EØS-området) der resepter i ett nordisk land skal ha gyldighet i alle de andre. Når alle landene har som mål at så godt som alle resepter skal være elektroniske, blir det vanskelig å oppfylle disse forpliktelsene.

\subsection{Hvilken løsning?}

Kartleggingen viser ikke bare at de nordiske landene er på ulike stadier i implementeringen av sine nasjonale e-reseptordninger, men også at man har valgt ulike løsninger i de ulike land.

Spørsmålet om et felles nordisk legemiddelmarked ble blant annet diskutert på Ministermøte i Oslo i 2007 og på møtet ble det også vist til at det ble arbeidet med elektroniske resepter i alle de nordiske landene. I en pressemelding fra dette møtet oppsummerer Finlands Social- och hälsovårdsminister Liisa Hyssälä ministrenes syn på spørsmålet om en felles nordisk e-reseptløsning.

«Både i Finland och de övriga nordiska länderna utvecklas som bäst system med elektroniska recept. Enligt minister Hyssälä skulle det i princip vara bra om de nordiska länderna tog i bruk ett gemensamt system för elektroniska recept. Ministern konstaterade ändå att det är mer ändamålsenligt att bygga upp systemen i de egna länderna först.

Det har visat sig vara en tämligen utmanande uppgift att bygga upp nationella system för elektoniska recept. På grund av detta befarar jag att ibruktagandet av ett gemensamt system skulle fördröja processen att ta i bruk systemen i det egna landet, sade minister Hyssälä.» ${ }^{17}$

\footnotetext{
${ }^{17}$ http://www.stm.fi/sv/pressmeddelanden/pressmeddelande/view/1226375
} 
Dette er utvilsomt en fornuftig tilnærming, ikke minst i erkjennelsen av at flere av landene allerede har kommet langt ut utvikling av sine løsninger og at noen av løsningene allerede er i mer eller mindre rutinemessig bruk. Det er også en helt korrekt observasjon at det har vært, og er, store utfordringer knyttet til det å bygge opp de nasjonale systemene. Dette har man også fått erfare i Norge i forbindelse med oppstart av piloteringen i Versjon 1. ${ }^{18} 19$

Samtidig er det klart at det å bygge opp og utvikle nasjonale løsninger uavhengig av andre lands valg og systemer gjør det vanskeligere å få på plass et over- og mellomnasjonalt system. Et system for ekspedering av elektroniske resepter i alle de nordiske land må være slik at det kan fungere sammen med alle de nasjonale systemene. Samtidig skal ikke en slik løsning være en trussel mot sikkerheten i de enkelte lands e-reseptordninger og den skal sikre pasientenes rettigheter og krav til effektivitet og kvalitet. Dette er ingen enkel oppgave.

Basert på det arbeidet vi har gjort, finner vi det vanskelig å vurdere nærmere hvordan en slik løsning kan eller bør være. Valg av løsning tror vi i stor grad vil være et teknologisk spørsmål og vil kreve teknologisk kompetanse for å utrede. Grunnlag og muligheter for en teknologisk løsning må kvalitetssikres nærmere i en egen prosess.

Basert på våre funn ønsker vi likevel å peke på noen mulige løsninger:

\subsubsection{Meldingsutveksling}

En elektronisk resept er - eller kan være - en elektronisk melding. Elektroniske meldinger har alle de nordiske land bred erfaring i å bruke og teknologien er velkjent og sikker.

Utfordringen ved å ta i bruk meldingsutveksling til vårt formål er blant annet at det ikke finnes noen nordisk standard for elektroniske resepter. Det gjør at en resept skrevet ut i ett nordisk land kanskje kan sendes over til et annet, men den vil ikke uten videre være lesbar hos mottakeren. Ved meldingsutveksling over landegrensene må man også etablere ordninger for identifisering av avsender og mottaker, kryptering av meldinger og identifisering av pasienten som kommer på apoteket for å ta ut medikamenter basert på resepten.

\subsubsection{Tilgang til de nasjonale systemene}

Et alternativ til utveksling (sending) av meldinger kan være å gi tilgang inn til de nasjonale e-reseptsystemene for apoteker i de andre nordiske land. I et slikt system kunne man tenke seg at en nordisk borger oppsøker et apotek i et naboland, identifiserer seg og på en eller annen måte autori-

\footnotetext{
${ }^{18}$ http://www.apotek.no/sw27847.asp (11.05.09)

${ }^{19} \mathrm{http}: / /$ www.dagensmedisin.no/nyheter/2008/09/24/datakollaps-slettet-100-00/index.xml (11.05.09)
} 
serer apoteket til å aksessere den elektroniske resepten som ligger i hjemlandets system.

Vi tror ikke dette vil være en god løsning, og kanskje heller ikke mulig å få til i praksis. Det å skulle gi tilgang mellom de nasjonale systemene fra og til en hel mengde apoteker rundt om i de nordiske landene vil i seg selv være en utfordring i forhold til ivaretakelse av sikkerheten. Hver aksess vil kreve en form for «åpning» inn i det sikrede nasjonale systemet, og vi vil anta at nasjonale tilsynsmyndigheter vil stille seg kritisk til dette.

En ordning med tilgang til de nasjonale reseptdatabasene vil antakelig kreve omfattende endringer i de nasjonale lovverk.

\subsubsection{Felles nordisk e-reseptdatabase}

Man kan tenke seg etablering av en felles nordisk database for elektroniske resepter. En slik database måtte være et sted dit elektroniske resepter fra et nordisk land blir sendt/lagt inn slik at de kan aksesseres fra et apotek i et annet. Løsningen forutsetter at det kan etableres tilfredsstillende sikkerhet både knyttet til lagring av informasjon i databasen og til kommunikasjonen mellom databasen og aktørene i de respektive land.

Det vil antakelig være en utfordring å få klare ansvarsforhold knyttet til en slik database. Noen må være databehandlingsansvarlig for systemet og bruken av og kommunikasjon med basen må risikovurderes av de nasjonale systemene.

\subsubsection{Nordisk e-reseptportal}

I sitt svar på vår kartlegging peker Island på at det å etablere en felles portal kan være en løsning for å få til behandling av elektroniske resepter mellom de nordiske landene. Dette kan være en løsning for å «komme rundt» problemet med de ulike måtene reseptinformasjon kommuniseres på i de ulike landene og også for å løse problemet med ulike standarder. Island har selv valgt en portalløsning for sitt e-reseptsystem.

Også en nordisk reseptportal må forankres et sted og noen må være ansvarlig for etablering, drift og vedlikehold. Hvis vi forstår det islandske forslaget riktig vil man imidlertid i en slik portalløsning i svært liten grad lagre informasjon. I forhold til å ivareta informasjonssikkerheten er jo det en klar fordel.

\subsection{Anbefaling}

Norden har alle forutsetninger for å bli en foregangsregion i Europa når det gjelder elektroniske resepter. Dette gjelder både på nasjonalt plan og, ikke minst, regionalt - mellom de nordiske landene. Denne rapporten og 
vår kartlegging har vist at man i Norden har gode forutsetninger, juridisk, organisatorisk og teknologisk, for å kunne utvide nasjonale systemer for elektronisk resept til en regional løsning.

De nordiske landene er som nevnt også forpliktet gjennom avtaler og nasjonale lovverk til å anerkjenne bruk av resepter fra hverandres nordiske land. Dersom de nordiske landene skal kunne oppfylle denne forpliktelsen, må man finne en løsning for grenseoverskridende resepthåndtering. I Norden kommer papirresepten til å forsvinne i løpet av forholdsvis få år.

En nordisk e-reseptløsning må også sees i sammenheng med andre initiativer og prosjekter for grenseoverskridende telemedisin og e-helse. De nordiske landene har alle tatt i bruk informasjonsteknologi i helsesektoren - på noen områder i stort omfang. Norden er også en del av Europa og på europeisk plan pågår det mye arbeid for å fjerne hindringer også for helsetjenester over landegrensene og for å gjøre det enklere for pasienter å søke helsehjelp i andre europeiske land.

Vi har allerede nevnt epSOS-prosjektet. Dette prosjektet er viktig og interessant både fordi det inkluderer to av de nordiske landene og fordi prosjektet skal se på elektroniske resepter. Ikke minst viktig er det at prosjektet skal se på såkalte «basic datasets» for e-resept. Skal man få til kommunikasjon og formidling av informasjon må man ha enighet om i alle fall noen fundamentale standarder.

I vår anbefaling til Ministerrådet for videre arbeidet på dette feltet vil i trekke frem to sentrale funn i vår kartlegging og i arbeidet med denne rapporten:

- De nasjonale e-reseptløsningene er tatt i bruk og implementert i ulik grad

Ifølge kartleggingen er mellom 50 og 75 prosent av reseptene i

Sverige og Danmark elektroniske. Tallet er omkring 30 \% på Island, mens både Finland og Norge er i ferd med å starte opp og pilotere sine løsninger

- Det europeiske epSOS-prosjektet er i ferd med å gjennomføre en pilot for elektronisk resepthåndtering mellom Danmark og Sverige Funn og erfaringer fra dette prosjektet vil kunne få direkte betydning for en felles nordisk løsning. Vår vurdering er at det ikke er formålstjenelig eller effektivt å sette i gang et prosjekt som kan være i konkurranse med det man ønsker å gjøre i epSOS. Man må også anta at Sveriges og Danmarks innsats på området vil bli lagt ned i dette prosjektet.

På bakgrunn av dette er det vår anbefaling til Nordisk Ministerråd at Rådet gir Nordisk eHelseforum fortsatt mandat til å arbeide med sikte på at Norden skal få én felles løsning for håndtering av elektroniske resepter mellom landene i regionen. Forumets oppgave skal være å holde seg ori- 
entert om utviklingen på området og være et kontaktpunkt mellom de nasjonale prosjektene og andre, relevante, prosjekter. Forumet skal fortløpende vurdere om det er behov for å konkretisere det nordiske samarbeide på dette området ytterligere og skal kunne fremme forslag om dette til Ministerrådet.

Nordisk eHelseforum skal aktivt arbeide for å få til et samarbeid med av epSOS prosjektet og andre relevante prosjekter og initiativer. Forumet skal også kunne tilby sin kompetanse til denne type prosjekter, innenfor de rammene forumet og Ministerrådet setter.

Fokus på elektroniske resepter skal være ett av Nordisk eHelseforums primærfokus i tiden fremover.

Status og utvikling i forhold til målet om en felles Nordisk løsning for elektronisk resepthåndtering evalueres og rapporteres slik Ministerrådet ønsker det etter ett år - sommeren 2010. 



\section{Vedlegg 1. Linker}

\begin{tabular}{|c|c|}
\hline Danmark & \\
\hline www.sundhed.dk & Den danske helseportalen \\
\hline www.sum.dk & Ministeriet for Sundhed og Forebyggelse \\
\hline www.sst.dk & Sundhedsstyrelsen \\
\hline www.laegemiddelstyrelsen.dk & Lægemiddelstyrelsen \\
\hline \multirow[t]{2}{*}{ www.medicin-it.dk/ } & Medicinprofilen \\
\hline & $\begin{array}{l}\text { «Medicinprofilen er en samlet oversigt over hver } \\
\text { enkelt borgers recepter og køb af medicin på } \\
\text { recept. Medicinprofilen giver både borgeren, } \\
\text { lægen og apoteket et samlet overblik over den } \\
\text { receptordinerede medicin, borgeren er i behand- } \\
\text { ling med.» }\end{array}$ \\
\hline www.medcom.dk & Det danske sundhedsdatanet. \\
\hline www.datatilsynet.dk & Det danske datatilsyn \\
\hline \multicolumn{2}{|l|}{ Island } \\
\hline http://www.heilbrigdisraduneyti.is/ & Helsedepartementet \\
\hline http://www.landlaeknir.is/ & Helsedirektoratet \\
\hline http://www.tr.is/ & State social security institute \\
\hline http://www.personuvernd.is/ & Datatilsynet \\
\hline \multicolumn{2}{|l|}{ Sverige } \\
\hline http://regeringen.se/social & Socialdepartementet \\
\hline www.socialstyrelsen.se & Socialstyrelsen \\
\hline www.apoteket.se & Apoteket AB \\
\hline http://www.apotekensservice.se & Apotekens Service AB \\
\hline www.datainspektionen.se & Datainspektionen \\
\hline \multicolumn{2}{|l|}{ Finland } \\
\hline www.stm.fi & Social- og hälsovårdsministeriet \\
\hline http://www.thl.fi/sv_SE/web/sv & $\begin{array}{l}\text { Institutet för hälsa och välfärd. } \\
\text { «Institutet för hälsa och välfärd (THL) är ett } \\
\text { forsknings- och utvecklingsinstitut inom social- } \\
\text { och hälsovårdsministeriets förvaltningsområde.» }\end{array}$ \\
\hline http://www.tietosuoja.fi/1559.htm & Dataombudsmannens byrå \\
\hline \multicolumn{2}{|l|}{ Norge } \\
\hline www.regjeringen.no/hod & Helse- og omsorgsdepartementet \\
\hline www.helsedirektoratet.no & Helsedirektoratet \\
\hline http://www.helsedirektoratet.no/samspill/eresept/ & Om det norske eResept-prosjektet \\
\hline www.helsetilsynet.no & Helsetilsynet \\
\hline www.legemiddelverket.no & Statens legemiddelverk \\
\hline www.datatilsynet.no & Datatilsynet \\
\hline
\end{tabular}





\section{Vedlegg 2. Kartleggingsskjema}

Elektronisk formidling av resepter - kartlegging Land: Kartleggingen utført av': Kontaktinformasjon (epost):

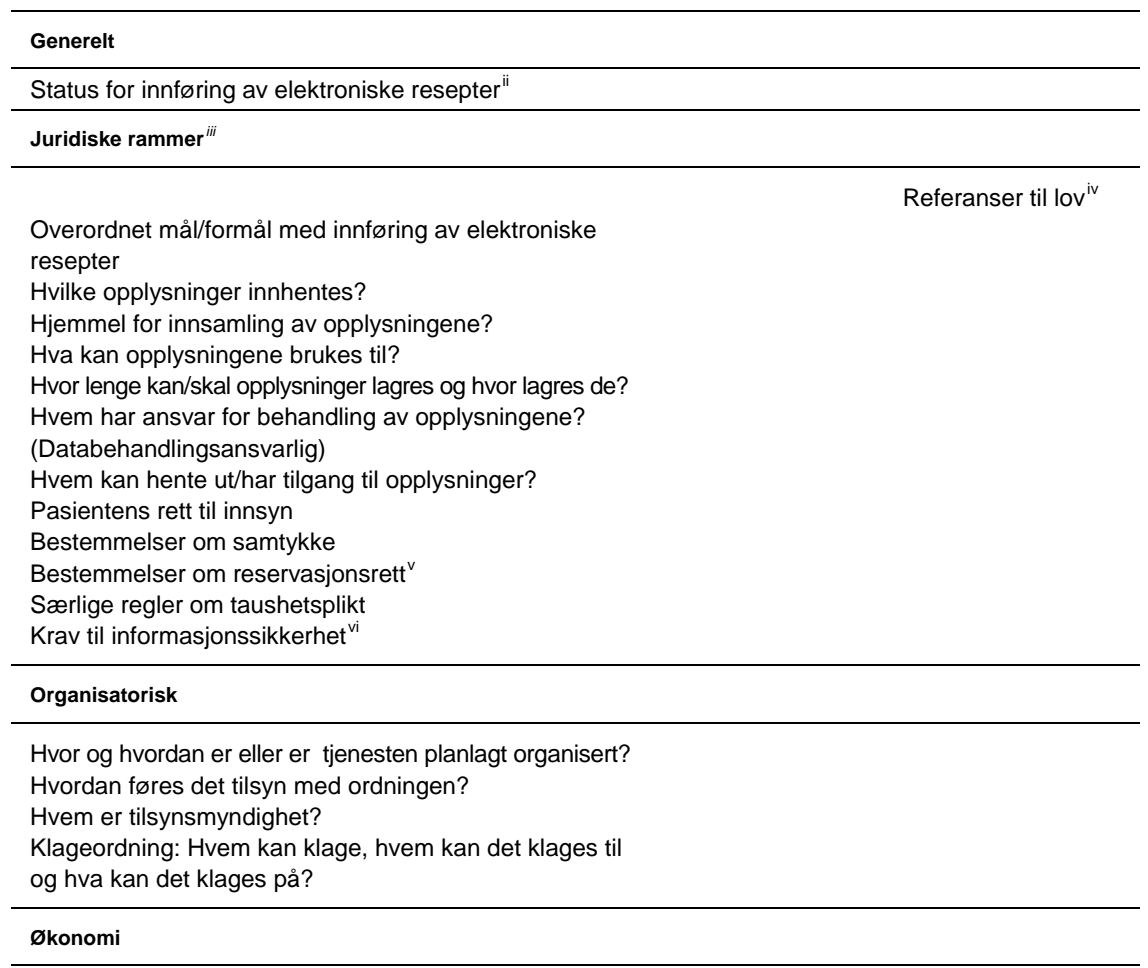

Kort beskrivelse av rutiner og ordninger for betaling av reseptbelagte medikamenter

Betalingsordning for resepter fra andre nordiske land ${ }^{\text {vii }}$ 
Teknologisk

Overordnet beskrivelse av systemet

Hvordan gis tilgang til systemet?

Kryptering

Referanse til relevante standarder som benyttes

Annen relevant informasjon om teknologisk løsning

Annet ${ }^{\text {viii }}$

\footnotetext{
${ }^{i}$ Navn og arbeidssted for den/de som har fylt ut skjemaet

ii Kort beskrivelse av status for innføring av elektroniske resepter. Dersom e-resept er tatt i bruk, hvor stor prosent av reseptene er elektroniske?

iii Denne delen skal forsøke å gi et bilde av likheter og ulikheter mellom de nasjonale lovverkene

${ }^{\text {iv }}$ Linker til lovtekst

${ }^{v}$ Kan pasienter nekte å bruke elektronisk resept?

${ }^{v i}$ Hvilke krav som stilles i lovverket, for eksempel ved henvisning til standard eller lignende.

${ }^{v i i}$ Hvilke rutiner har man for betling/oppgjør for resepter fra andre nordiske land $i$ henhold til gjeldende ordning med gjensidig godkjenning av resepter?

viii Fritekst. Annen informasjon som vurderes som relevant for kartleggingen.

Her ber vi også om en kort vurdering av det du/dere mener er de største hindringene for etablering av en løsning for e-resept over landegrensene i Norden.
} 